\title{
Muinaskarjala vaimuvara
}

Abram Stoljar

Die Geisterwelt ist nicht verschlossen;

Dein Sinn ist zu, dein Herz ist tot!

Auf! Bade, Schüler, unverdrossen

Dein'ird'sche Brust im Morgenrot.

Goethe, Faust

Euroopa taiga ja tundra asustamine ülempleistotseeni ajajärgul oli tõeliselt kangelaslik ettevõtmine. Inimese tungimist põhjaaladele võib pidada ajalooliseks sündmuseks, mis käivitas ülimalt dünaamilise ideoloogilise protsessi. See kajastub ka Karjala muinastaides, mille leiualad moodustavad idapoolseima osa Fennoskandia leiualade võrgustikust (joonis 1).

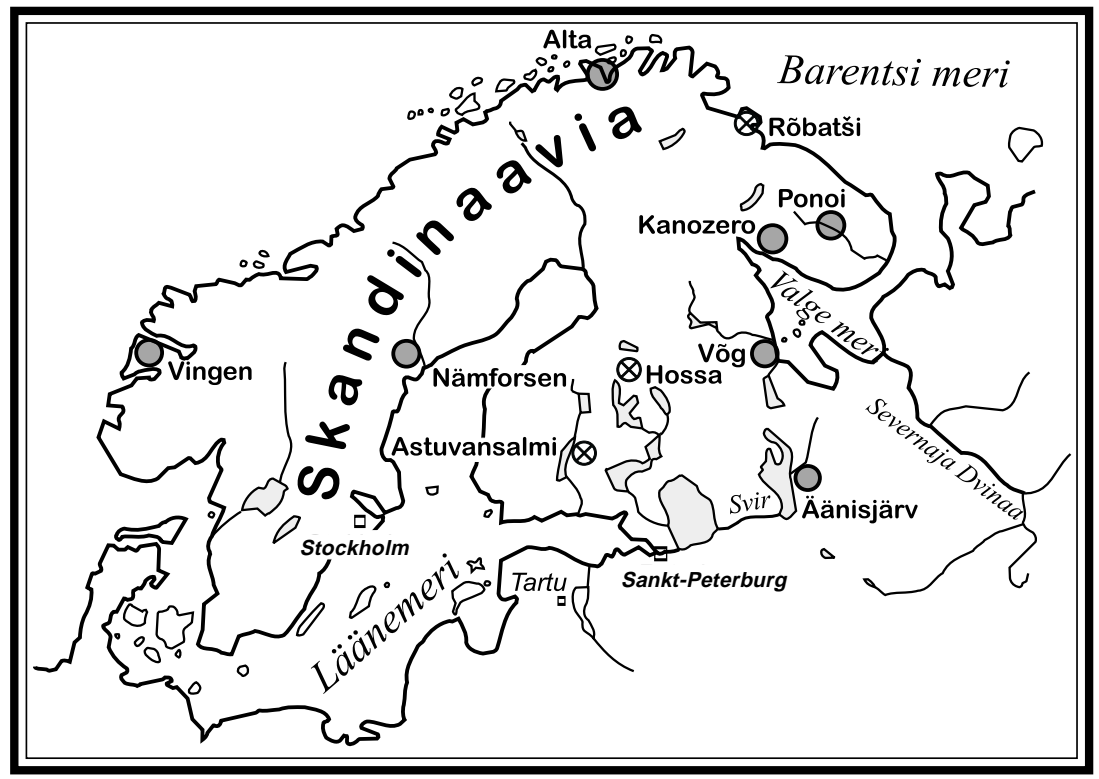

Joonis 1. Muinastaide leiualasid Fennoskandias. Kaart: V. Poikalainen. 


\section{Oleni saare kalmistu}

Karjalas Oleni saarel (soome keeles Peurasaari) asuvad matmispaigal on eriline tähtsus aitamaks mõista mesoliitikumiaegses Fennoskandias valitsenud pingelist sotsiaalset ja ideoloogilist õhustikku. Suurima seni teadaoleva kiviaegse matmispaigana Euroopas on Peurasaari kalmistu ka üks olulisimaid Põhja-Euroopa kiviaegseid leiukohti ning pärineb tõenäoliselt aastatest 5500-5000 eKr.

Kalmistu asub Äänisjärve kirdeosa väikesel Oleni saarel (joonis 2). Neotektooniliste uurimuste põhjal võib arvata, et mesoliitikumis oli saar oma mõõtmetelt veelgi väiksem, moodustades künkliku maalapi (oletatavad mõottmed $1,27 \times 0,27 \mathrm{~km}$ ), mis ulatus vaid mõned meetrid üle veepinna.

\section{Uurimislugu ja leiuaines}

Esmalt väärib tähelepanu muidugi selle "surnute saare" kalmistu kolossaalsus. Aastatel 1936-1938 V. Ravdonikase juhtimisel läbi viidud välitöö käigus avastati 177 luustikku (Ravdonikas 1940). Et suurem osa kalmistust hävis hilisema paekivikaevandamise käigus, võib arvata, et algselt oli seal vähemalt 400 luustikku (Arheologija 1996). See üllatavalt suur arv on aga vastuolus hõredavõitu asustusega nende ääretute põhjaalade hõlmamise aegu. Nii ulatuslikke matmispaiku ei kohta isegi Palestiina varaholotseeni kultuuris, kus rahvastiku tihedus pidi olema mitu korda suurem.

Oleni saare matmispaiga erakordsusest räägib veel tõik, et saarele ei maetud kaugeltki kõiki surnuid (näiteks laste ja noorte haudu ei leidu peaaegu üldse). Samuti ei maetud kalmistule aasta läbi, vaid ainult soojadel aastaaegadel (tõenäoliselt hiliskevadest hilissügiseni). Pealegi vajati iga matuse puhuks saarele seilavat meeskonda.

Teiseks selle (Põhjala) mesoliitilise ideoloogia arheoloogilise baromeetri huvipakkuvaks tunnusjooneks on sakraalsuse selge vastandumine igapäevase eluga. Geograafiliselt paikneb kalmistu elupaikadest ebatavaliselt kaugel; samuti on ala hämmastavalt lage kõikvõimalikest juhuleidudest: kogu $2700 \mathrm{~m}^{2}$ suuruselt pinnalt on väljaspool kalmeid leitud vaid neli eset.

Alles mesoliitikumis asendusid üksikkalmed kalmistutega. Kalmistutel on oluline roll nii etnilise kuuluvuse kui ka tollase ideo- 


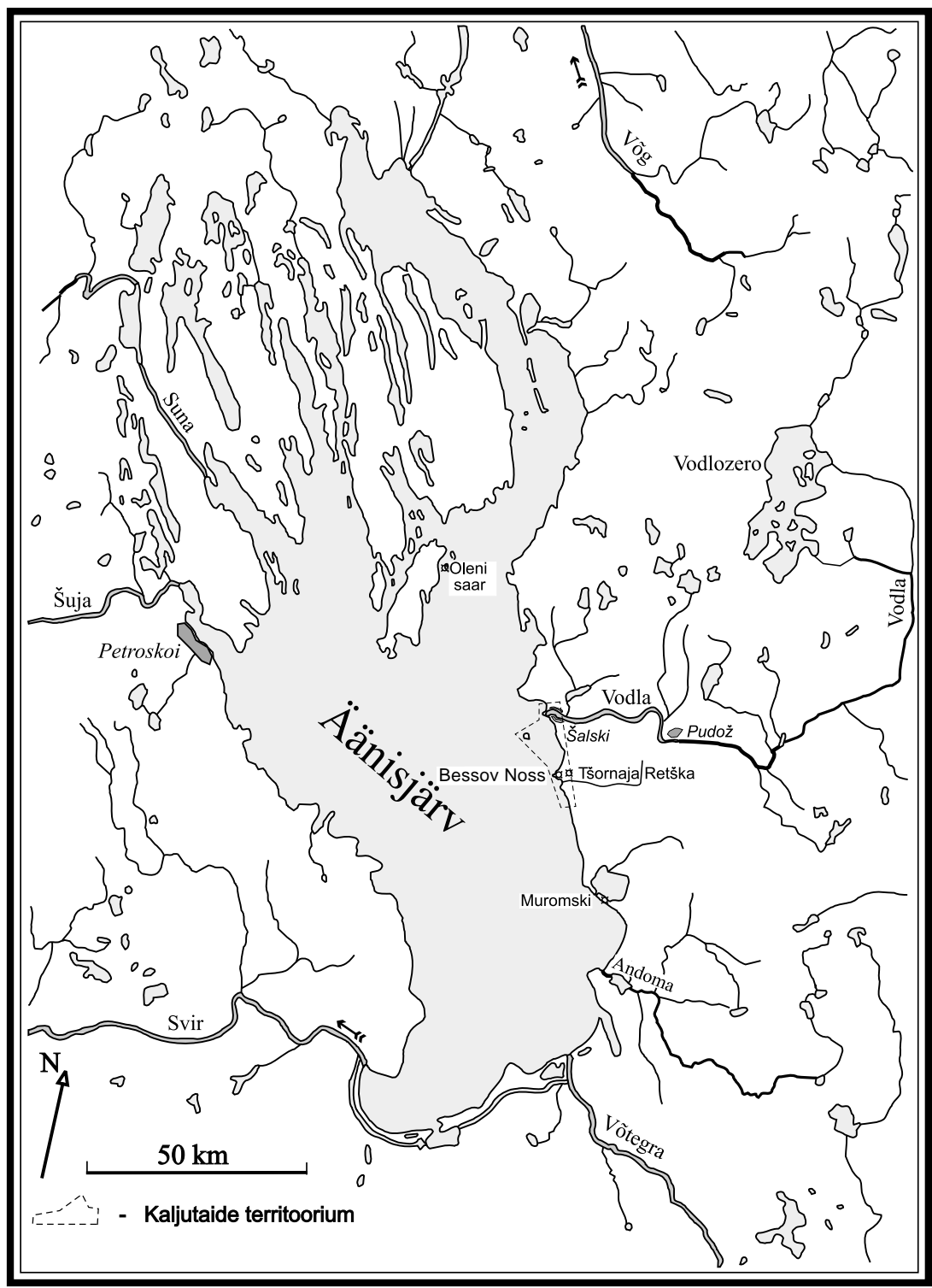

Joonis 2. Ä̈̈nisjärv. Kaart: V. Poikalainen. 
loogia mõistmisel, sest need peegeldavad elu mõtet käsitlevate arusaamade arengut. Selles kontekstis esindab Oleni saare kalmistu arhailiste arusaamade mitmekülgset kajastust teispoolsust kui eraldiasetsevast paigast nii otseses kui kaudses tähenduses.

Lisaks eelmainitud tunnustele ilmneb selle ainulaadsus $\mathrm{ka}$ hauapanustes, mille arv on tähelepanuväärne (kokku 7132 leidu).

Alalt pole leitud tööriistade toormaterjali ega nukleusi ning avastatud on vaid üksikuid tööriistu, mis mesoliitikumi asulakohtades on muidu tavapärasteks leidudeks (kalmudest tuli päevavalgele vaid 4 kõõvitsat ja üks peitel, moodustades $0,1 \%$ kõikidest leidudest).

Mesoliitiliste asulakohtade teiseks omapäraks on vibuküttimisega seotud esemed: kivist ja luust nooleotsi esineb neis sadade kaupa.

Oleni saare hauapanustest on aga arvukaimalt esindatud rituaalsed muistised. Kõige enam on leitud loomakihvu: põtrade läbipuuritud lõikehambaid (4372 eksemplari 84 matuses, vähemalt 739 indiviidilt) ja kobraste lõikehambaid (1155 eksemplari 70 matuses, vähemalt 547 indiviidi), samuti läbipuuritud karukihvu (170 eksemplari 48 matuses) (Gurina 1956).

Karukihvad koos oletatavalt rituaalseks otstarbeks kasutatud kiltkivist nugadega (60 tk 30 matuses) on samuti sagedased hauapanused.

Figuratiivset taiet (põdrasarvest nikerdatud kujukesi) on 14 ehk enam kui kogu piirkonna mesoliitilistes asulakohtades kokku.

Enamik neist kujutavad põtru ning järgivad stiililt ülempaleoliitilist taidetraditsiooni. Vaid üks (fragmentaarne) skulptuur esindab tervet looma; kaheksal juhul on kujutatud põdra pead. Kolm suuremat põdrapeafiguuri on klassikalised Põhja-Euroopa animalistliku muinastaide esindajad. Neil vinklikujulistel "sauadel" esineb arvukalt analooge metsavööndi leidude hulgas. Taieste paiknemise põhjal ühiskalmus nr 55-57 ja eeskätt matustes nr 152 ja nr 153, ning tuginedes Äänisjärve idaranna kaljudele raiutud kujutistele, mis ilmselt kujutavad samu sakraalseid esemeid, võib arvata, et need olid lisandid, mis kinnitusid puust saualaadsete esemete külgedes olevatesse avaustesse. Neis võib näha atribuutikat, mis tunnistab maetu kõrget ühiskondlikku positsiooni. Ülejäänud viis väikest lapikut põdrapead kuulusid arvatavasti samasuguste sauade väiksemate mudelite juurde (joonis 3 ). 
Antropomorfse pisiplastika traditsioon, mis paleoliitilise taide arengus oli sekundaarne, on esindatud kolme eksemplariga, kusjuures igaüks neist järgib oma arenguliini. Esimene neist on piklik pulgataoline naisefiguur, mis järgib ülempaleoliitikumi skemaatilist kaanonit. Teine skulptuur on lame mehekujutis, tõenäoliselt üldistatud protokangelase tüüp. Vibu kasutuselevõtuga küttimisel võidi tõepoolest hakata rõhutama meessoo ja esivanemate kultuse tähtsust ühiskonnas. Kolmas, kahenäolise Januse sarnane kujuke näib aga eriti müstiline just seetõttu, et kajastab püüdu kujutada enamat kui vaid ühte persooni. Võimalik, et see skulptuur jätkas Madeleine'i ajastu kunstnike traditsiooni kehastada "inimest kui sellist", ühendades mees- ja naissoo iseloomulikud tunnused ühte taiesesse (joonis 4).

Kohalikust ornamenteeringu traditsioonist (mis pidi olema üsna levinud kuigi raskesti tõestatav, kuna tegemist oli enamjaolt orgaaniliste materjalidega) võib saada aimu kaheksa esemeleiu mustrite põhjal. Keerukaim, nurkadest ja siksakkidest koosnev reljeefne muster esineb kalmust nr 44 avastatud liivakivifragmendil. Teine, nikerdatud siksakmuster, samuti äärmiselt harvaesinev, kaunistab kalmust nr 100 leitud unikaalse luust pistoda ühte poolt (vt allpool) (joonis 5).
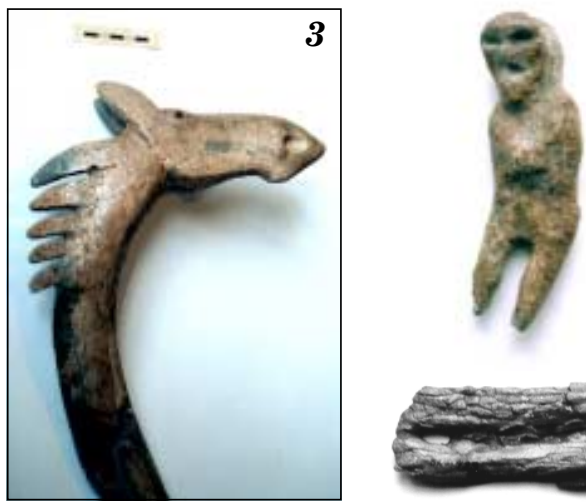

$4 a 4 b$

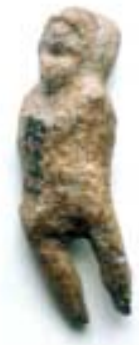

Joonis 3. Oleni saare kalmistu põhjapõdralaadne sau (Kunstkamera kogudest. Foto: V. Poikalainen.

Joonis 4. Oleni saare kalmistu kahenäoline inimfiguur (Kunstkamera kogudest. Foto V. Poikalainen.

Joonis 5. Luust pistoda Oleni saare kalmistust (Kunstkamera kogudest. Foto: V. Poikalainen. 


\section{Kalmistu etnogeneetiline tähtsus}

Üks olulisimaid Oleni saare kalmistuga seotud küsimusi puudutab selle teket ja etnosotsiaalset tähtsust.

Demograafilisest aspektist vaadelduna esindas matmispaik inimhulka, mis oli suurusjärgu võrra suurem kui ükskõik millise Äänisjärve piirkonna selleaegse asulakoha elanikkond. Oletatavasti kasutas kalmistut ulatuslikuma ala (näiteks Povenetskaja Guba ümbruse) rahvas ühiselt. Povenetskaja Guba on suurim laht Äänisjärve kirdeosas, ning otsustades mesoliitikumi asulakohtade tiheduse järgi, pidi see tolleaegsete korilaste seas olema eriti soositud. Oleni saar asub aga lahesuudme lähistel (vt joonis 2).

Kahtlemata kasutati kalmistut mitme sajandi vältel. Selle ajaloost on aga senini väga vähe teada. Praegugi võime vaid spekuleerida kalmistule aluse pannud esimese matuse teemal. Võiks lähtuda eeldusest, et sellise kalmistu teke oli erakordne sündmus, mis avaldub esimese matuse ebatavalisuses.

Ülalmainitud tingimustele vastab täielikult matus $\mathrm{nr} 100$, mis on tõepoolest unikaalne. See tugeva kehaehitusega keskealise mehe kalm erineb teistest eeskätt vertikaalse matmisviisi, aga ka uskumatult rikkalike hauapanuste poolest (joonis 6). Inimjäänustelt leiti 500 eset, mis moodustas viieteistkümnendiku kalmistu kõigist leidudest. Kalmu teevad eriliseks veel teisedki asjaolud, muu hulgas selle väga varajane radiosüsinikudateering.

Joonis 6. Matus $\mathrm{nr} 100$ (foto: Peterburi Ülikooli Muuseumi kogudest).

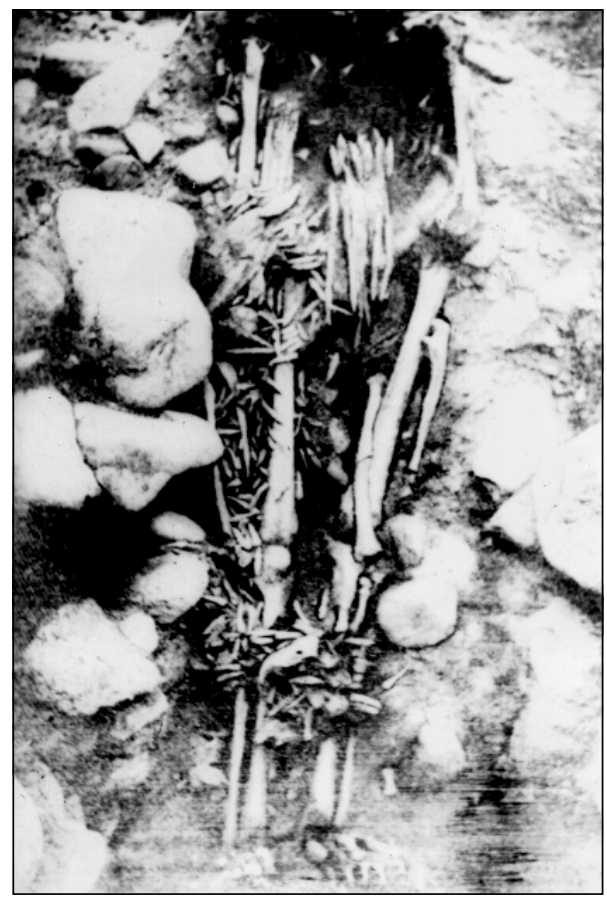


Väljakaevamiste käigus avastatud luustiku asend annab tunnistust sellest, et lahkunut oli võimalik kohalviibijaile eksponeerida. Sellega kaasnevat visuaalset efekti aitas tugevdada mitte ainult surnukeha paiknemine (püstine, rangelt frontaalne asend), vaid ka olulised semantilise tähtsusega leiud (nooltega tupp ja suur mikroliitidest teraga luust pistoda) (vt joonis 5).

Kalmu ebatavaline ehitus (avar haud, surnukeha varjanud suured kivid, mida eraldas skeletist õhuke liivakiht) ning mitmed rituaalsed tunnusjooned, muu hulgas ka horisontaalne ookrilaik ja leiud surnu lõualuu lähedal, näitavad, et talle ohverdati veel kaua pärast matmist. Võimalik, et haud avati rituaalseteks toiminguteks näopoolsest küljest kas täielikult või osaliselt (mis on tõenäolisem). Igatahes on täiesti kindel, et mesoliitikumiaegsed inimesed haudu avasid. V. I. Ravdonikas avastas 13 juhtu, mil varasematesse kalmudesse oli ilma neis midagi rikkumata kuni kolm korda osavalt peale maetud (Ravdonikas 1940).

Ka kalmistu üldplaan ning eriti asjaolu, et kalmud ei kattu, kuigi asetsevad tihedalt üksteise kõrval, viitab sellele, et hauad märgistati mingi tähisega, arvatavasti puutulbaga. Matust nr 100, mida peeti ka kõige väärikamaks kalmuks, tähistas ilmselt eriti suur tulp, mis oli asetatud otsapidi hauda (rööbiti surnukehaga). Kuna surnu isik ajapikku mütologiseerus, omistati ka tulbale antromorfseid jooni ning see omandas sümboolse tähenduse. See võiks olla ka üheks võimalikuks seletuseks metsavööndi muinaskultuuride üheks eripäraks peetavate monumentaalsete puuiidolite tekkele (Stoljar 1995b).

Seega pidi nekropol sündima kõrge positsiooni ja mõjuvõimuga inimese matmisest. Selle matuse erakordsus seostub tihedalt "surnute saare" üldise emotsionaalse õhustikuga. "Surnute saare" mõiste tähistab kulminatsiooni muistse elanikkonna suhtumises oma esivanematesse.

Milline võis olla seda kalmistut ümbritsev etniline ja kultuuriline taust?

Kalmistu tekke sügavamaid juuri tuleks otsida varaholotseenis aset leidnud lõunapoolsete isoleeritud inimgruppide spontaanses rändes põhjapoolsetele aladele ning nende järkjärgulist tungimist metsavööndi kaugeimatesse nurkadesse.

Osa neist jäi lõpuks pidama Povenetskaja Guba ümbruskonda, kus nad leidsid eest soodsad tingimused. Kõige tõenäolisemalt erinesid need inimrühmad üksteisest nii geneetiliselt kui ka kultuuriliselt. Ajapikku vähenesid rühmadevahelised erinevused nii 
asustajate sarnase majandusliku tausta kui ka ühesuguse kohanemisstrateegia tõttu. Kõiki laheranniku asulakohti ühendavate veeteede olemasolu suurendas kultuurilist homogeensust.

Kõige olulisem oli siiski psühholoogiline tegur. Kuna paikne elu piiratud maa-alal karmides põhjamaa tingimustes oli väga üksluine, ületas sotsiaalsete ja rituaalsete kontaktide vajadus isegi utilitaarseid tarbeid. Kõige tõhusamaks ja arvatavasti ka ainsaks vahendiks keskkonnast tingitud stressiga võitlemisel osutusid suurejoonelised sümboolsed rituaalid. Rohked arheoloogilised ja etnograafilised allikad tõendavad rituaalide olemasolu enamikus, võimalik, et ka kõikides muinaskultuurides.

Emotsionaalne ja vaimne vajadus konkreetse ideoloogilise keskuse järele näibki olevat olnud selle hiiglasuure nekropoli tekkimise peapõhjus muidu hõredalt asustatud piirkonda. Pealegi ei suuda tänapäeva intellektuaal, nendesamade inimeste järglane, aimata esmaasukate tugevaid tundeid ega hirme, mis pidid neid valdama üleminekul nomaadluselt paiksele eluviisile võõras keskkonnas.

Emotsionaalsete probleemide lahendamiseks tuli Povenetskaja Guba elanikel ületada lõhe mineviku ja oleviku vahel. Tõhusaimaks vahendiks osutus esivanemate kultus.

Oma uue kodumaa keskele "surnute ilma" rajamine oli võrreldav pikaajalise rände käigus "liigestest lahti" läinud ajakulu restaureerimisega. Piirkonda asustanud elanikel tuli selle täideviimiseks ühendada oma jõud. Seega võib kalmistut vaadelda ka kui tükikest kivistunud ajalugu.

Oleni saare kalmistu iseloomulikud tunnusjooned viitavad mesoliitilisele kuldajale, mil matmispaigad täitsid etnokultuuriliste pühapaikade rolli. On tähelepanuväärne, et kuigi nii bioloogiline kui kultuuriline materjal rõhutavad nn Oleni saare populatsiooni märgatavat heterogeensust, ühendas kogu Äänisjärve kirdeala ühtseks tervikuks rituaalne sfäär.

Ühistel matusetoimingutel olid väga olulise tähtsusega tagajärjed. Ehk nagu Auguste Comte on öelnud: Surnud valitsevad elavate üle. Esivanemate ilma võimendamisega liitsid surnud ürgloogika jõul oma järglaskonna ühtseks tervikuks.

Rituaalses sfääris peitubki seega võti mõistmaks Põhja-Euroopa etnilise, keelelise ja kultuurilise esmase arengu tekkemehhanisme. Määravaks teguriks etniliste kontaktide tekkel ja väiksemate inimrühmade sulandumisel kõrgematasemelisteks etnilisteks üksusteks oli pigem ideoloogia kui majanduslik heaolu. 
Inimfenomeni vaimse olemuse samasugust arengut neoliitikumis tõendavad Karjala kaljujoonised. Ka siin tuleb ilmsiks terav kontrast koriluselu ja vaimse kultuuritasandi vahel, mida ei anna vähimalgi määral seostada üdlevinud arvamusega sellest piirkonnast kui tagurlikust ja isoleeritud maanurgast. Inimtemaatika ja inimese sotsiaalse võimekuse jõulise kajastamise aspektist võib Karjala kaljutaiet pidada teatud mõttes isegi avangardseks.

\section{Äänisjärve kaljujoonised}

Äänisjärve idakaldal ja Valge mere rannikul Võgi jõe suudmes leiduvad kaljujoonised kuuluvad Fennoskandia neoliitiliste küttide muinastaide viie tähtsaima leiuala sekka. Iga uue avastusega ilmnevad selle ainulaadse kogumi ühistele tunnustele lisaks ka erinevate $\mathrm{nn}$ petroglüüfigaleriide iseärasused, mis tõendab muu hulgas muistse Põhjala erakordset kultuurilist mitmekesisust.

\section{Uurimislugu ja aines}

Selle monumentaalse "kivikroonika" uurimisele, mida alustasid V. Ravdonikas ja A. Linevski juba enne Teist maailmasõda ning mis sõjajärgseil aastail jätkus J. Savvatejevi ja teiste juhtimisel, andis uue tõuke ajavahemikul 1982-1996 Eestis V. Poikalaineni juhtimisel tegutsev rahvusvaheline Eesti Muinastaideselts (joonis 7). Lisaks arvukatele senini teadmata üksikjoonistele ja Vodla suudmes kahe täiesti uue leiukoha avastamisele on need uuringud oluliselt täiendanud asjaomast andmebaasi (Poikalainen \& Ernits 1990; Poikalainen 1994). Siinkohal üritan selle andmete abil tõlgendada teadaolevaid fakte ajaloolisest aspektist. Selleks tuleb:

1) Äänisjärve kaljujooniste algupära ja teket vaadelda põhjaalade neoliitikumiaegses kontekstis;

2) analüüsida järveäärse pühamu etnokultuurilist olemust;

3) püstitada hüpoteesid petroglüüfide semantilise tausta kohta.

Alustada võiks aga kõige tähtsamast ideograafilisest grupist, nimelt Bessi neeme kaljujoonistest.

Äänisjärve ja ka teiste kaljujooniste uurimisel on traditsiooniliselt ilmnenud teatav suundumus, mis on sageli osutunud eksitavaks. Enamik autoreid näib olevat alustanud hoopis valest ko- 
Joonis 7. Äänisjärve kaljujooniste leiukohad. Kaart: V. Poikalainen.

hast, nimelt on neil mingil moel õnnestunud kahe silma vahele jätta arheoloogiliste uuringute peamine eesmärk taastada iga leiukoha ja selle osade võimalikult üksikasjalik arengulugu. Leiukohtade joonistel kujutatut on sageli käsitletud tänapäeva vaatevinklist ehk pigem üheaegselt loodud terviku kui eri perioodidest pärinevate elementide mosaiigina.

Ometigi esitas Linevski

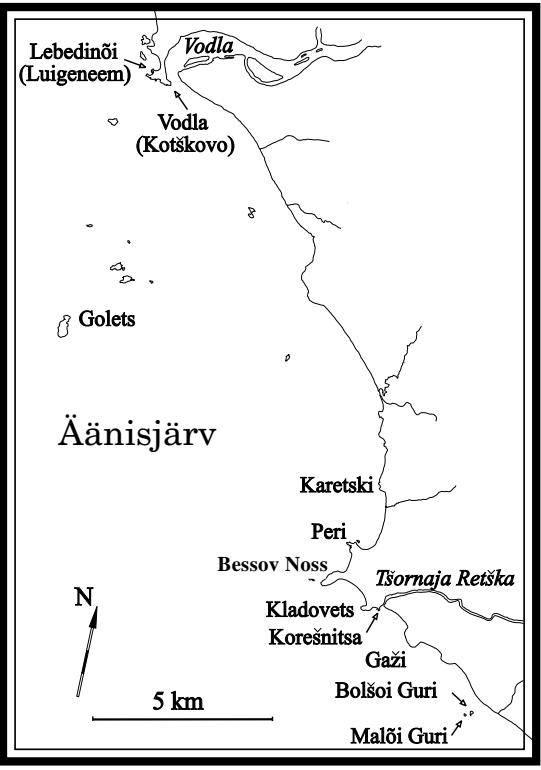
juba 1939. aastal Bessi neeme kaljudel kujutatud peamiste figuuride suhtelise kronoloogia ja tema algatust tuleks kindlasti jätkata. Rakendades nn topograafilist meetodit (mis kujutab endast leiukoha piires esinevate kujutiste paiknemise analüüsi looduslike reljeefielementide suhtes) avastas ta, et kolm hiiglaslikku sümboolset joonist, mida siin ja edaspidi olen nimetanud Triaadiks, moodustavad ühtse kompositsiooni. Vastupidiselt traditsioonilisele käsitlusele tõestas Linevski veel, et Triaadi keskne, nn Kuradi (vene k "Bess") figuur on neist kolmest vanim (Linevski 1939).

Linevski käsitlusele toetudes võiks üritada kronoloogiliselt järjestada kõiki Äänisjärve galeriis esinevaid kaljujooniseid. Selleks kasutame alljärgnevaid kriteeriume:

1) iga Äänisjärve idakalda joonistega kaljuneeme makrotopograafilist eripära;

2) iga petroglüüfide rühma mikrotopograafiat, kusjuures erilist tähelepanu tuleb pöörata kattuvate ja mittekattuvate kujutiste kronoloogilisele järjestusele;

3) sobivat arheoloogilist argumentatsiooni.

Esimene kriteerium võimaldab võrdlevalt hinnata iga kaljuneeme tähtsust kogu "panteoni” geograafilises süsteemis. Teise abil 
hinnatakse antud leiuala jooniste tõenäolist ajalist järjestust igas rühmas eraldi, arvestades loodusliku ümbruse eripära, lähestikuste kujutiste omavahelisi seoseid ning kõrgust veepinnast, mis määras varasemate jooniste asukoha kaljul.

Arheoloogilist argumentatsiooni aga kasutan Triaadi hiidkujutiste mesoliitikumiaegsete prototüüpide määramiseks ning hilisemate väiksemate jooniste võrdluseks 3 . at keskpaigast kuni 2 . at alguseni eKr pärinevate ränikujukestega. Makrotopograafilisest aspektist on leiualal mõjuvaimaks Bessi kaljuneem, mis tungib 700 meetri pikkuse kiiluna järve ning domineerib mitme kilomeetri pikkusel rannajoonel. Joonised paiknevad neeme tipus veepiirilähedastel graniitkaljudel. Just siin näib "ruunide meri" lähemal kui kusagil mujal ning selle ürgjõud on hõlpsasti tajutav.

\section{Pühamu teke ja esmane areng}

Triaadi hiiglaslikud kujutised (keskosas Bess ehk Kurat (2,46 meetrit), vasakul Saarmas (2,56 m) ning paremal Kala $(2,65 \mathrm{~m})$ paiknevad mikrotopograafilisest seisukohast kõige eelistatumas pisut kaldus pinnaga (kallakunurk alla 20 kraadi) kalju alumises vööndis.

Asjaolu, et need erakordselt suured kujutised moodustavad äärmiselt korrapärase rühma, hõlmates umbes 30 ruutmeetri suuruse pinna, annab tunnistust sellest, et enne nende jooniste loomist pidi läikiv ja kõrbevaabast pruunikas kaljupind olema täiesti kasutamata ja sile.

Kõigele lisaks ei ole kohavalikut mõjutanud mitte niivõrd kunstitehnilised eelistused, kuivõrd rituaalsed ja sümboolsed põhjused. Linevski tähelepanekutest ilmneb, et oletatavasti esimesena loodud Bessi kujutis ühtib ülitäpselt kaljupinna mõningate pisidetailidega. Kuradi trapetsilaadse eestvaates keha poolitab sümmeetriliselt kaheks sirge pragu, mis ilmselt on vanem kui joonis ise. Samuti paikneb ta nägu nii, et suu jääb kohakuti väiksema lõhega, mis moodustab keskjoone ühe haru (Linevski 1939).

Motiivi äärmiselt keerukas sobitamine loodusliku taustaga pidi eeldama head kujutlusvõimet ja oskusi. Tulemus on aga midagi enamat kui lihtsalt kunstiline saavutus, kuna see kehastab iidoli toitmise ideed (sellise tõlgenduse pakkus esimesena välja Linevski ise). Kuradi parema käe all kujutatud kala (arvatavasti sterlet) võibki vihjata rituaalsele toidule. 


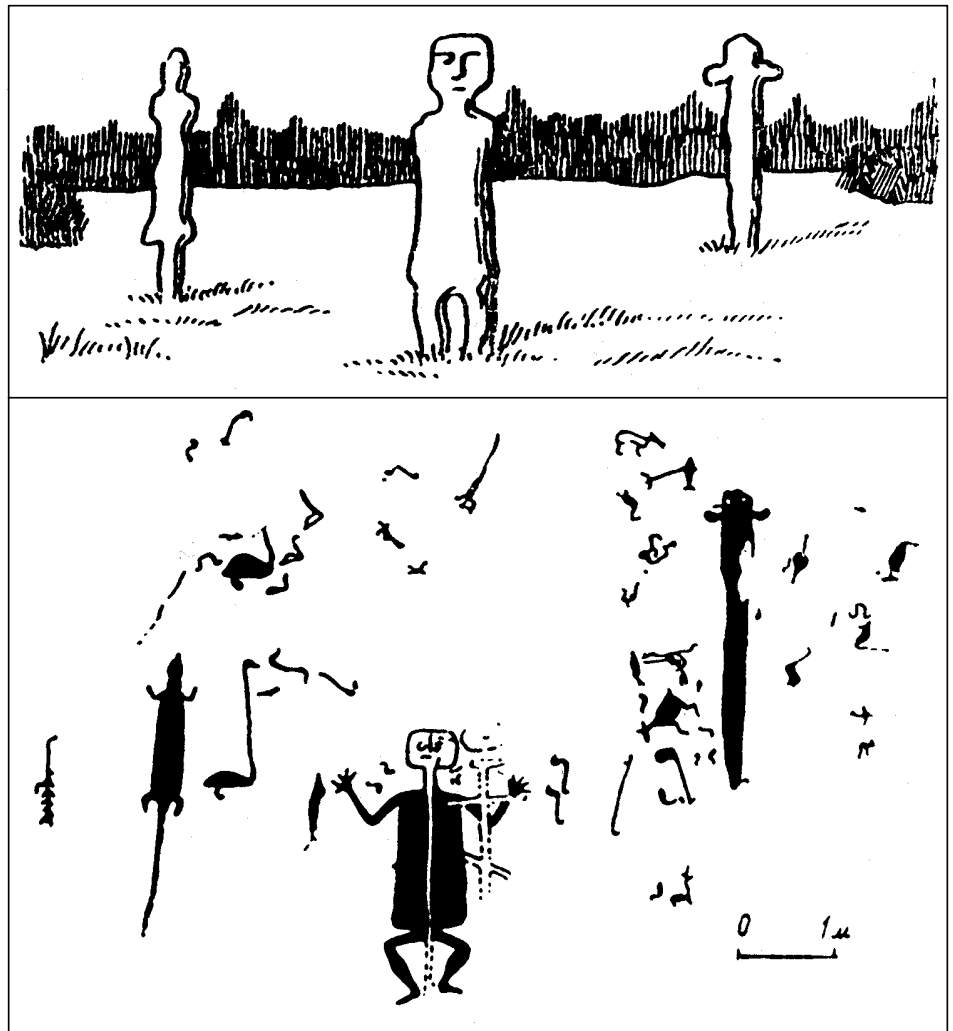

Joonis 8. Puuiidolid ja nende transformatsioon kaljujoonisteks.

Nii rituaalse toitmise idee, söögitoru sümboliseeriv telgjooneline kaljulõhe ja ebajumala võime võtta heatahtlikult vastu kui tahes suurt toiduhulka ning eriti iidoli keha puunotisarnane geomeetriline vorm annab alust oletada, et motiiv pärineb monumentaalsetelt antropomorfsetelt puuskulptuuridelt (joonis 8). Sellised skulptuurid olid metsavööndi mesoliitikumi ja neoliitikumi kultuurides üsna levinud. Traditsiooni hoiti alal isegi veel möödunud sajanditel. Mõningad puuiidolid on tänu soodsatele mullastikutingimustele säilinud Läänemere idaaladel (Sārnate, Šventoji II ja teised leiukohad). 
Alles nüüd tundub olevat võimalik teha kindlaks, millest on tekkinud need monumentaalsed antropomorfsed puuskulptuurid, mis tihti loodi puunotti vaid üksikute kirvelöökidega töödeldes seega peaaegu sümboolse toiminguga. Võtmeks on juba eespool mainitud Oleni saare mesoliitikumiaegse matmispaiga ainulaadne kalm nr. 100, mis tõendab selgelt esivanemate kultuse siirdumist uuele tasemele. Selle abil on võimalik jälgida ühe ideelise sümboli nelja arenguetappi: (1) "naturaalne märk" (kõrge positsiooniga mehe vertikaalne matus); (2) antropomorfne sümbol (tulp) - maapealne kalmutähis; (3) puust iidol, mis oli juba omandanud iseseisva tähenduse; ning viimaks (4) selle "vari” petroglüüfina Äänisjärve kaljuneemel. Viimase semantiline tähendus pidi ilmselgelt peegeldama ka kogu arenemislugu.

Kui siinkohal esitatud mõttekäik paika peab, pärineb Triaad tüüpilisest hiiepühamust, kus palvetajad, kes lähenesid pühamule teatud suunast, sattusid vastakuti püstiste postilaadsete puuiidolite hõreda reaga. Kiviaja kunstnike kujutlusvõime oli aga liiga piiratud, et selliseid kujutisi instinktiivselt luua niivõrd ulatuslikule kaljupinnale (Saarma ja Kala omavaheline kaugus on 6 meetrit). Tõenäolisemalt tingis kolme kujutise hiidmõõtmed ning paiknemise ikkagi rituaalsete puuskulptuuride kasutamise traditsioon, kaljujoonistest sai nende "petroglüüfiline ilming" (Stoljar 1978). Skulpturaalsete prototüüpide teooriat toetab ka asjaolu, et keskse joonise (Kuradi) ees seistes ei ole võimalik vaadelda tervet Triaadi korraga.

Kõik ülalesitatud tähelepanekud, aga ka allpool käsitletud raiumise tehnikaga seotu peaks andma piisavat tunnistust selle kohta,
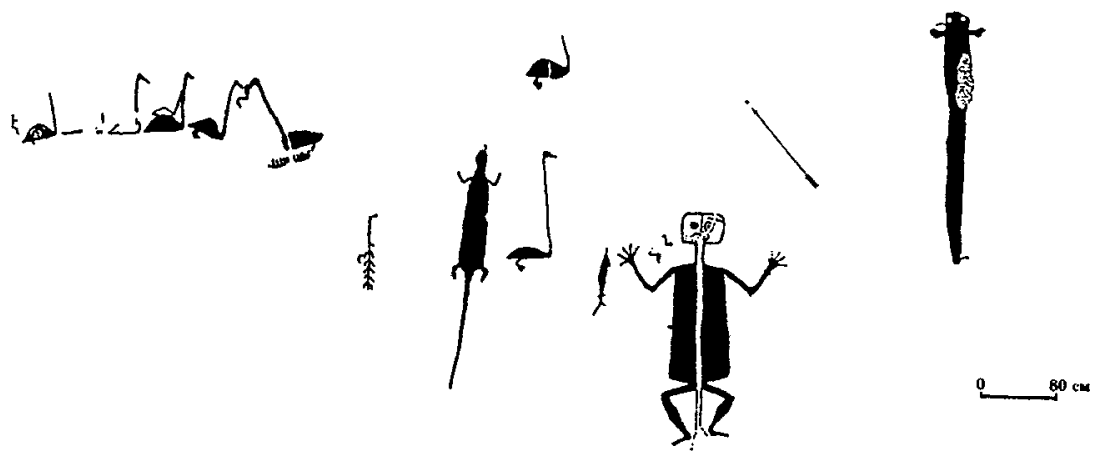

Joonis 9. Bessi lääneneeme esmased joonised. 
et Triaad oli Äänisjärve galeriis esimeseks kompositsiooniks (joonis 9). Selle vanust on võrdlemisi raske täpselt määrata, sest neoliitikumi kronoloogilised piirid on liialt hägused. Samuti ei võimalda täpset dateerimist veetaseme kõikumiste uurimine. Kõige tõenäolisema hinnangu järgi ulatus Triaadist madalamal olev kaljupind veepiirist kõrgemale ajavahemikus 5 . at lõpust kuni 2 . at alguseni eKr.

Ühe tänapäevase absoluutse dateerimise meetodi abil on puuduv informatsioon siiski tuvastatav. Selle meetodi rakendamisele aitas kaasa asjaolu, et samale kaljule on arvatavasti 15. sajandil raiutud kaks õigeusu risti. Linevski oletas, et kaljujooniste dateerimiseks võiks kasutada päikesekiirguse mõjul kaljupinnas toimunud füüsikaliste muutuste ulatust (Stoljar 1994b). 1991. aasta rahvusvahelise väliseminari Eclipse käigus tuli samale mõttele Austraalia teadlane R. Bednarik (Bednarik 1992). Kahe petroglüüfi, Kuradi ja sellega kattuva suure risti mikroerosiooni analüüsi abil määras ta $\mathrm{Ku}-$ radi absoluutseks vanuseks 2000 a eKr. Seda dateeringut tuleb aga korrigeerida, sest 2 . at algul eKr jäi Triaad vee alla ning seega enam kui tuhandeks aastaks päikesekiirguse eest varjule. Lisades selle aja Bednariki dateeringule, saame Kuradi kõige tõenäosemaks loomisajaks 4. at keskpaiga või lõpu eKr.

Siinkohal tuleks aga juhtida tähelepanu ühele näilisele vastuolule. Äänisjärve galeriile on iseloomulik, et iga jooniserühma vanimate petroglüüfide paiknemine vastab tolleaegse veepinna kõrgusele. Mõned kujutised loodi tõenäoliselt vaid $1-2 \mathrm{~cm}$ veepinnast kõrgemale. See ei kehti aga Kuradi puhul, kelle jalad asuvad praegusest veepiirist $46 \mathrm{~cm}$ kõrgemal, ning veelgi vähem Triaadi külgmiste kujutiste puhul. Niisugust ebareeglipärasust on lihtne seletada sellega, et Triaad oli nii oma asetuse kui ka tähtsuse poolest pühamu keskseks jooniserühmaks. Oluline on ka tõik, et Triaadi ümbritsevad väiksemad kujutised asuvad veepiirist veelgi kaugemal. Seega pidid rituaalidest osavõtjad seisma Kuradi jalgade ja veepiiri vahelisel kaljuribal. Suure Kala ja Saarma kõrgem paiknemine ning ka ulatuslik distants kõigi kolme joonise vahel näib olevat tingitud praktilistest kaalutlustest, sest kõige "loomulikum" rituaalis osalejate asetus on poolringikujuline rivi, mis võimaldas neil individuaalselt pöörduda iga sümboli poole.

Triaad on kogu Äänisjärve galerii võtmekompositsioon. Selle teevad eriliseks nii kujutiste arvestatav suurus kui ka silmapaistvalt oskuslik ja detailne loomistehnika, millele aastatel 1971-1974 
osutas R. Klimov. Nimelt on jooniste siluetid raiutud äärmiselt ühtlaste löökidega. Kuna need on olnud küllaltki täpsed, samas mitte liiga tugevad, on saadud äärmiselt korrapärane teravate piirjoontega uurend. Selline tehnika, mis võis järgida varasemaid taidetraditsioone alates maapinnale joonistamisest (geoglüüfid) kuni pehmematele kaljupindadele joonistamise või kriipimiseni, tagas ajahambale peaaegu muutumatult vastu pidanud kujutised.

Mitmedki kaljupinna ülaosa petroglüüfid on hävinud (vt allpool). Säilinutest sarnanevad loomistehnika poolest Triaadile kõige enam järgmised joonised:

a) põhigalerii ehk Tšornaja Retška regiooni suurim luigekujutis (arvestamata Vodla jõe suudme petroglüüfe), see asub otse teispoolsust sümboliseeriva Saarma kõrval;

b) Saarmast vasakule jääb külgvaatelistest kujutisest koosnev joonisterühm, mis pärineb arvatavasti arhailise loomeperioodi lõpust ning sisaldab reas ujuvaid luiki, inimest ja paati (seda ideogrammi üritan ka allpool tõlgendada).

Need joonised, mis oma stiililt meenutavad varasemaid petroglüüfe, on arvatavasti loodud temaatika semantilise ja kompositsioonilise rikastamise käigus 4 . at lõpust kuni 3. at keskpaigani eKr ehk lakustriinse pühamu algperioodi jääva 500-700 aasta kestel.

Samade kriteeriumide põhjal võib varasemasse arenguperioodi liigitada veel järgmised petroglüüfid (Stoljar 1995a):

c) Peri VI: suured päikese- ja kuusümbolid nende juurde kuuluva pikavarrelise "saua" kujutisega (joonis 10);

d) Peri III: kaks suurt päikesesümbolit koos suurima "sauaga" nn katuseks nimetataval kaljul, mida säilitatakse Sankt-Peterburgi Ermitaažis (joonis 11).

Tuleb märkida, et sauade pikavarreliste puust prototüüpide (mis olid tõenäoliselt algelised tunnussümbolid) põdrapäiseid ja põdrasarvest valmistatud lisandeid leiti Oleni saare kalmistu ilmselt kõrge positsiooniga isikute haudadest. Teine asjaolu, mis tõestab sauakujutiste sakraalset seost selle mesoliitilise kalmistuga - "Suure Vee" taga "Loojuva Päikese Maal" paikneva esivanemate mütoloogilise elupaigaga -, on see, et Peri VI neemiku tüüpiline sau on orienteeritud umbes $50 \mathrm{~km}$ kaugusel asuva Oleni saare suunas (Stoljar 1983). Seda võib vaadelda muinasaja mõttemaailma teatud iseloomuliku aspektina, mida meie võime küll vaid oletada. Sarnaselt Bessi neeme kaljulõhe antropomorfsele käsitlusele annab seegi tunnistust aegade jooksul akumuleerunud ideoloogilise kujutlus- 


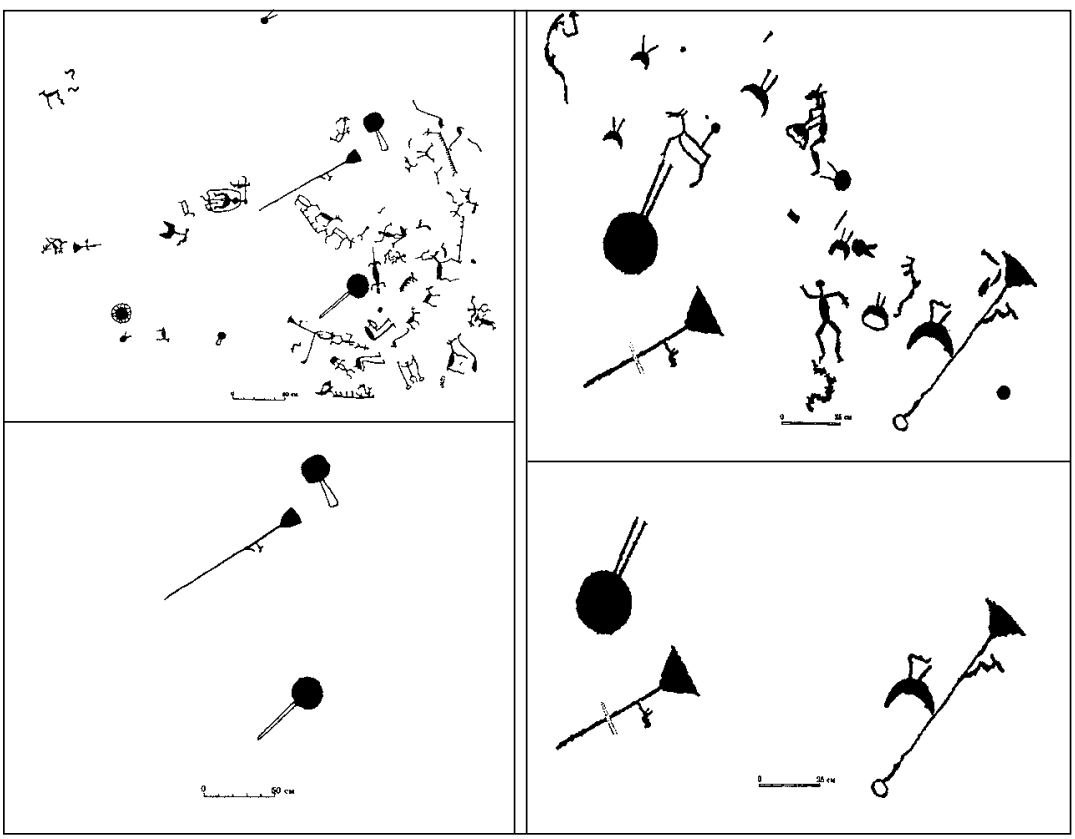

Joonis 10. Osa Peri III leiukohast Joonis 11. Peri VI joonispannoo ja ja selle esmased joonised. selle esmased joonised.

võime erakordsest rikkusest ning looduse hingestamise mitmekesisusest ja sügavusest inimmõtte poolt.

Seega koosneb Äänisjärve petroglüüfide vanim kihistu (kokku 20-25 kujutist) Bessi neeme aukartustäratavast altarist ja selle kahest spetsialiseerunud "harust", mis paiknevad oma monumentaalsete sümbolkujutistega maksimaalselt $1200 \mathrm{~m}$ kaugusele jäävatel põhjapoolsetel naaberneemikutel Peri VI ja Peri III.

Need Bessi neeme piirkonna nii mõõtmete kui paiknemise poolest ebatavalised kujutised moodustavad vähem kui 3\% kogu Tšornaja Retška regiooni jooniste kogumist. Seega on neid oluliselt vähem kui väiksemaid petroglüüfe, mille keskmine suurus on 25-30 cm ja mille koguarv Bessi neemel ületab 150 (nende hulk kogu regioonis ulatub üle 800 ).

Bessi neeme petroglüüfide duaalsus ei ole pälvinud teadlaste tähelepanu ega ergutanud neid uurima selle eripära ajaloolisi, ideoloogilisi või kunstilisi tagamaid. 


\section{Pühamu õitseng}

Võib oletada, et väiksemate kujutiste tekkele andsid tõuke radikaalsed muutused, mis olid tingitud äärmiselt dünaamilisest etnokultuurilise pingestumise ning keerukamaks muutumise protsessist. $10 \mathrm{~km}$ pikkusele rannaribale ja kahe saare neemedele tekkisid üheksa uut "kaljusaali”. Tšornaja Retška regiooni pühamute hiiglaslik tähtsus on võrreldav varasema Oleni saare kalmistu omaga, sest väga tõenäoliselt külastas neid kogu Äänisjärve idakalda elanikkond. Kõige olulisem on aga see, et võeti kasutusele uusi motiive, millest olid levinuimad metsloomad (põder, ulukpõhjapõder, karu), varem tuntud motiive (linnud ja antropomorfsed kujutised) aga täiustati. Tekivad mitmefiguurilised keerukaid ideogramme meenutavad kompositsioonid, kus väiksemad kuu- ja päikesesümbolid esinevad koos looma- ja linnukujutiste ning antropo- ja zoomorfsete joonistega. Mõned jooniste seos rannajoonega kaob ning neid luuakse kõrgematele kaljudele. Sellised joonised raiuti halli diabaasi, mis aga pole kuigi sobiv taust, samuti on selle pind ilmastikukahjustustele oluliselt vastuvõtlikum.

Vaevalt saab kõiki neid muutusi seletada kaljutaide autohtoonse evolutsioonilise teisenemisega. Pigem tähistavad need järjepidevuse katkemist, teatud etnosotsiaalsetest teguritest põhjustatud ootamatut ideoloogilist nihet.

Kujutiste suuruse 10-, 20- või isegi 25-kordne vähenemine on toimunud pigem äkki kui sajanditepikkuse järkjärgulise protsessi tulemusel. Samamoodi on suuri sümboleid hakatud kujutama väikeste märkidena (see kehtib nii päikese- ja kuukujutiste kui ka "sauade" kohta). Ainsaks erandiks võib seejuures pidada üksikuid suuri linnujooniseid, mis muistse maailmapildi (vt allpool) kesksete elementidena mängisid pühamus olulist osa. Tegemist oleks justkui salapärase vastuoluga, mille esmapilgul näib olevat tinginud kunstilise arengu spontaansus ja juhuslikkus. Sedasorti agnostiline tõlgendus osutub aga ajaloo analüüsi põhimõtete seisukohast lootusetult ekslikuks.

Isolatsionistlik lähenemine petroglüüfidele, kus iga joonisrühma käsitletakse nii teistest kunstivormidest kui ka elukorraldusest lahusoleva ning iseseisvana, muudab analüüsi paratamatult abstraktseks ja formaalseks. Üldjuhul leiab arheoloogilistele leidudele tuginedes harva vastuse küsimusele, millised olid konkreetsed sündmused, mis määrasid ajaloo kulgu. Antud alal oli senini ajaloo- 
sündmuste rekonstrueerimisest üldse loobutud, mis välistas võimaluse saada mingitki ettekujutust kontekstist, mille taustal kaljujooniseid loodi.

Tegelikult on kaljutaide käsitlemine omaaegses kultuurilises ja ajaloolises raamistikus oluliselt tõhusam vahend. Eriti tulemuslikuks peaks aga osutuma keskendumine piirkonna neile sündmustele, mis võisid kokku langeda ajaga, mil kunstiline kaanon tegi läbi suuri muutusi ja Äänisjärve kaljutaie saavutas arengu haripunkti. Selles kontekstis võib petroglüüfilist revolutsiooni pidada mingi uue etnokultuurilise situatsiooni ideoloogiliseks tagajärjeks.

Tõepoolest, 3. aastatuhande teisel poolel eKr leidis aset Volga valgala metsapiirkonnas elutsenud Volossovo-Garino hõimude massiline ränne põhjapoolsetele aladele. Kõige tihedamalt asustasid need hõimud Äänisjärve kagurannikut ning sellega külgnevaid alasid Arhangelski oblastis. Lisaks täiesti uuele arheoloogilisele kultuurile, mille kõige iseloomulikumaks tunnuseks on taimsete jäänustega poorne keraamika, tõid sisserändajad kaasa ka spetsiifilisi ideoloogilisi ja kunstilisi arusaamu.

Tegelikult osutuski uus ideoloogia kultuurilise substraadi põhiliseks rikastajaks, andes uue tõuke kohalikule kaljujooniste traditsioonile ning viies selle kulminatsioonile. Kuigi võti niisuguse tõlgenduse tarvis on juba pool sajandit olnud kasutatav, pole seda siiani rakendatud. Juba 1948. aastal võrdles S. Zamjatnin Volossovo kultuuri unikaalseid räniskulptuure (antropomorfseid ja zoomorfseid kujukesi ning kuu- ja päikesesümboleid) Karjala petroglüü-

Joonis 12. Ränikujukesi Moskva Riiklikus Ajaloomuuseumis.

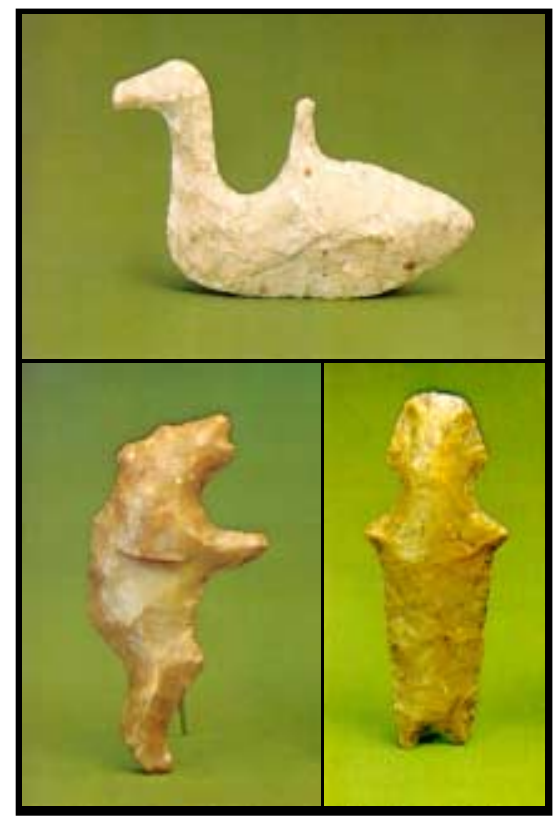


fidega ning jõudis äärmiselt läbinägelike tähelepanekuteni (Zamjatnin 1948). Sarnasus, mis kehtib vaid Äänisjärve kaljujooniste, kuid mitte Valge mere petroglüüfide puhul, on tõepoolest liiga märkimisväärne, et olla juhuslik (joonis 12). Samuti pole see seletatav mõlema taideliigi sünkroonse ilmnemisega. Sarnasuste hulka kuuluvad ka väga spetsiifilised motiivid, näiteks loom, kes kannab seljas astraalsümbolit. Nüüdseks teatakse teisigi, sugugi mitte vähem keerukaid kujutisi (vt allpool), mis esinevad nii räniskulptuuride kui ka nende petroglüüfidest "varjudena" Tšornaja Retška regiooni kaljudel.

Olemasoleva materjali põhjal on võimalik rekonstrueerida Loode-Venemaa muinasaja mõningaid episoode. Oma teise arengustaadiumi alguseks oli nii ajaliselt kui ka mõõtmetelt arenev Äänisjärve kaljupühamu muutunud kultuuridevaheliseks keskuseks, etnilise ja kultuurilise läbikäimise kohaks. Paigast oli saanud erinevate kultuuride sulatusahi, kus aastaaegadega seotud pühade ja rituaalide käigus tekkis lõpuks lokaalse ja Volossovo hõimude poolt sissetoodud kultuuride sulam. Sotsiaalset ja ideoloogilist progressi kiirendasid nii kiiresti kasvav elanikkond kui ka asjaolu, et kohalike ja sisserännanud hõimude kogukonnad olid teineteisele oma kultuurilise taseme poolest küllalt lähedased ehk - kasutades Teilhard de Chardini väljendit psychically interpenetrable - vaimselt läbitavad. Ideoloogiliste veendumuste ja nende avaldusviiside rituaalse sünteesiga kaasnes tõenäoliselt veel tegelik hübridiseerumine. Peri III ja Karetski petroglüüfirühmad tõendavad ka seda, et erinevate hõimude liikmete vaheliste segaabieludega kaasnevad riitused rõhutasid laste sünni teemat.

\section{Pühamu lõppfaas}

Tšornaja Retška regiooni petroglüüfide teist arengufaasi, mil Äänisjärve kaljutaidetraditsioon saavutas kulminatsiooni ning kiirenes kultuuridevaheline segunemine, võib hinnata umbkaudu 500 aasta pikkuseks. Sellest monumentaalsest pühamust loobumise põhjustasid eeskätt looduslikud tegurid, eriti aga Äänisjärve veetaseme transgressioon, mille maksimumi dateeritakse 2 . at algusse eKr. Selle protsessi käigus hakati Bessi neeme, Kladovetsi ja Karetski petroglüüfe looma veepiirist järjest kõrgemale, kuigi hallil graniidil jäid nad vähem kontrastseks. 
Kuna veetase jätkuvalt tõusis, ulatudes lõpuks kuni 2 m esialgsest kõrgemale, jäid mitmed joonised vee alla ja see asjaolu tekitas põliselanikes mitme põlvkonna vältel hirmu. Meil on raske ette kujutada sotsiaalse energia hulka, mida raisati kasutult looduse vastu võideldes. Katsetest väärata loodusjõude annab tunnistust mõnevõrra lohakalt raiutud linnufiguur, mis imiteerib $0,7 \mathrm{~m}$ kaugusel Saarma kõrval paiknevat luigekujutist. Veelgi märkimisväärsem on aga see, et Bessi neeme Triaadi kuuluva hiidsaarma kujutisest 4,7 m ülespoole, ilmastikust tugevalt kahjustatud diabaaspinnal, täpselt kujutise telgjoont pikendavas suunas asub teise, üsna suure (69 $\mathrm{cm}$ pikkuse) "saarma" tagaosa kujutav joonis (vt joonis 8). Kahe ühesuguse kujutise teadlik vastasseis viitab sellele, et ülemise vööndi erodeerunud pinnale pidi olema raiutud kas terviklik või osaline Triaadi koopia. Võimalik, et see oli peegelpildis, mis suunatud näiteks tõusvale veepiirile vastu. See annab vastuse küsimusele, kas Triaadi kummardati pühamu teises arengufaasis, mil kaljupinnale loodi arvukalt väiksemaid petroglüüfe. Vastus on jaatav ja viitab ühtlasi sellele, et peamised ideoloogilised komponendid püsisid visuaalsete sümbolitena tõesti väga pikka aega.

Reljeefi ja kaljupinna eripäraga arvestades oli võimalik vältida veepinna tõusust ohustatud pühamu kadu. Seda kinnitab Kladovetsi leiukoht, kus ülemised petroglüüfid asuvad 1,96 m praegusest veepiirist kõrgemal, Bessi neeme $(2,33 \mathrm{~m})$, eriti aga Karetski joonised (2,56 m) (Poikalainen 1995). Võib arvata, et just Tšornaja Retška regiooni põhjapoolseim Karetski neem oli paik, kuhu hääbuv pühamu üle viidi. Hiljem võeti vastu dramaatiline otsus viia pühamu veelgi kaugemale jäävatele kaljudele, kuna endine asukoht usuti olevat neetud.

Selleks valiti välja kolm kohta: Luigeneeme põhjakalju, Luigeneeme edelakalju ning Vodla jõe suudmeneem (Kotškovo). Kõik uued pühamud paiknesid Vodla jõe paremkalda regioonis, kohas kus jõgi suubub Äänisjärve, umbes 16 km Bessi neeme petroglüüfigaleriist põhja pool (vt joonis 2). Sellesuunalised esmased sammud võeti ette ajal, mil Karetskil oli rituaalsetes toimingutes veel keskne roll. Lõpliku otsuse asukoha muutmiseks kutsus esile aga ilmselt asjaolu, et uus paik sarnanes varasemale, kus pühamud jäid samuti jõe suudmest põhja pool olevaile neemedele. Uues kohas ei omistatud enam erilist tähtsust loomistehnilistele küsimustele, sest kõik Vodla piirkonna petroglüüfid on raiutud halli graniiti. Erinevalt Tšornaja Retška regioonist ei asetse ükski joonis madalamal kui 
$1 \mathrm{~m}$ üle veepiiri, suurimad kujutised ulatuvad aga $2,36-2,62 \mathrm{~m}$ veepiirist kõrgemale.

Vodla kaljupühamust on avastatud üle 300 kujutise. Uus kogum erineb mitmeti Tšornaja Retška galeriist. Kõige olulisemaks erinevuseks on linnukujutiste rohkus (66\% kõigist Luigeneeme ja $60 \%$ Vodla suudme joonistest). Paljud neist on seejuures üsna suured. Kõige tähelepanuväärsem on Luigeneeme põhjakalju hiidluik, mis 4,1-meetrisena ületab suuruselt isegi Triaadi kujutised ning on ühtlasi suurim enam kui tuhande Äänisjärve petroglüüfi seas (Poikalainen \& Ernits 1998). Üheks hiidkujutiste tekke võimalikuks seletuseks on see, et pühamu siirdamisele eelnes loometegevuse katkemine, millega kaasnes kanoonilise standardi leebemaks muutumine. Üldiselt võttes näib kolme Vodla regiooni galerii ideoloogiline sõnum olevat siiski sama mis Tšornaja Retška petroglüüfide puhul. Enamgi veel - siin on seda rõhutatud ja isegi fantaasiarikkalt hüperboliseeritud. Vodla leiukohti võiks seega vaadelda Äänisjärve kaljutaide arengu kolmanda ja viimase etapina.

\section{Kronoloogia ja tõlgendused}

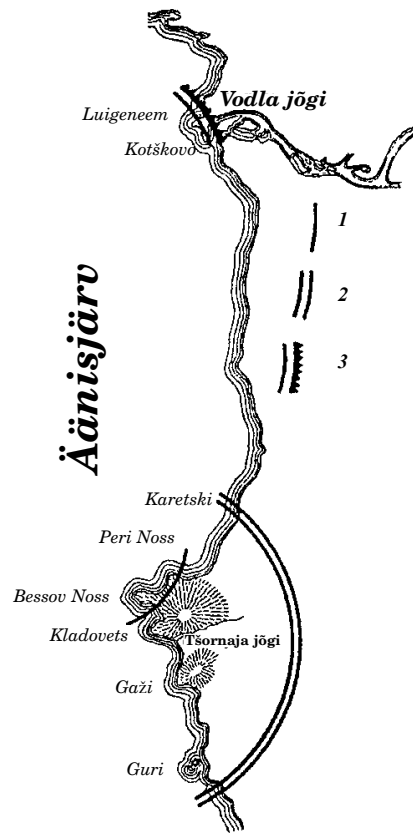

Seega saab "Kivisse raiutud kroonika" põhjal Äänisjärve muinasaja jaotada kolmeks järjestikuseks perioodiks (joonis 13).

\section{1) 4. at lõpp - 3. at keskpaik eKr}

Bessi lääneneemele oli tekkinud esmane kaljutaidekeskus. Selle kaks suurte kujutistega väiksemat kõrvalharu - Peri VI ja III - loodi naaberneemele. Võimalik, et lähedal asetsev asulakoht Tšornaja Retška I (Tšornaja Retška jõe suudme lähedasel paremkaldal) kuulus samadele inimestele, kes lõid pühamu. Oma surnuid võisid selle asukad matta Kladovetsi neeme väikesele kalmistule.

Joonis 13. Ä̈̈nisjärve kaljutaideala areng. 
Seega on meil pidepunkte nii kohaliku neoliitilise kogukonna materiaalse kultuuri kui ka vaimsete pürgimuste kohta. Petroglüüfide levinuimad motiivid - päikese- ja kuusümbolid - võisid olla inspireeritud suurepärasest elamusest, mida pakkus päikese ja kuu ringkäik mõõtmatu järve kohal.

\section{2) 3. at keskpaik - 2. at algus eKr}

See oli lokaalse pühamu plahvatusliku laienemise, täienemine ja interkulturaalseks sakraalseks keskuseks kujunemise periood. Varasem side Tšornaja Retška asulakohaga näib olevat katkenud ning kogu 10-kilomeetrine rannikupiirkond muutunud hõimuriituste ja -pidustuste läbiviimise kohaks. Selle äärmiselt jõulise arengu põhjuseks oli ilmselt kahe ideoloogia interaktsioon - ühelt poolt Äänisjärve põliselanikud, teiselt poolt aga sisserännanud Volossovo-Garino hõimud. Kultuuride sulandumise tulemusel ilmusid nii mõnedki Volga metsavööndi piirkonna räniskulptuuride motiivid petroglüüfide temaatikasse. Nende mõju ilmneb ka jooniste vähenenud mõõtmetes, mis viitab loomingulises traditsioonis väiksemate skulpturaalsete vormide eelistamisele.

\section{3) 2. at keskpaik eKr}

Tšornaja Retška peamiste jooniserühmade jäämisel vee alla viidi pühamu üle Vodla suudmeala neemede avatud kaljudele, mille graniit polnud jooniste taustaks kuigi sobiv, kuid mis asusid veepiirist oluliselt kõrgemal (uued asukohad sarnanesid aga varasematele Bessi neeme omadele). Järjest enamate petroglüüfide kattumist veega pidasid mitmed põliselanike põlvkonnad traagiliseks sündmuseks. Nendes tingimustes vähenes kultuuriline transmissioon ning rõhutati Tšornaja Retška kultuuritraditsiooni keskset ideed - irratsionaalsel loogikal põhinevat animistlikku teooriat, mis pidi seletama elu mõtet.

Ülalesitatud argumente tuleks muidugi ka põhjendada. Äänisjärve kaljutaide "pühasid paiku" külastades on võimatu mitte mõelda petroglüüfide semantilisele tähendusele. See probleem, millega puutusid esimestena kokku juba Bessi neeme ja Peri III joonisgaleriide avastajad Grewingk ja Šved, on pälvinud teenimatult vähe tähelepanu tänapäeva teadlaste hulgas. Kuigi värskemad teadustööd kubisevad üldistavatest väidetest, on 150-aastast uurimislugu arvestades petroglüüfide semantilist tähendust puudutavad saavutused siiski napid. 
Muidugi sõltuvad tulemused tihti ka paradigmast, millel põhineb konkreetse uurija meetod. Nende põhimõtete tähtsust rõhutab kahe sõjaeelse juhtiva teadlase A. Linevski ja V. Ravdonikase pikemaajaline dispuut. Mõlemal teadlasel on olnud märkimisväärne roll, kuna just nemad seostasid Äänisjärve petroglüüfid Euroopa muinastaidega.

Linevski, kelle järeldused põhinesid enamasti kainel loogikal, vaatles kaljukunsti igapäeva elu detailse peegeldusena. Tema arvamuse kohaselt olid petroglüüfid oma ajastu fotodeks (Linevski 1939).

Ravdonikas võitles ägedalt Linevski naiivsevõitu ja ratsionalistliku lähenemise vastu ning üritas põhjendada oma ideid filosoofiliste teooriatega primitiivse inimmõistuse ja selle arvatavate arengusuundade kohta. Ravdonikas uskus, et petroglüüfid peegeldavad elu vaid seniks, kuni seda peegelpilti ei moonuta muistse inimese mentaliteedi iseärasused (Ravdonikas 1937a, 1937b).

Tõepoolest ei kajasta kaljutaie kaugeltki kõiki tegeliku elu aspekte. Mõned väga olulised jooned jäeti hoopiski tähelepanuta. Kõige märkimisväärsemaks näiteks võiks siinkohal olla nende küttide ja korilaste põhitoit kala, mida esindab vaid $0,2 \%$ kõigist petroglüüfidest.

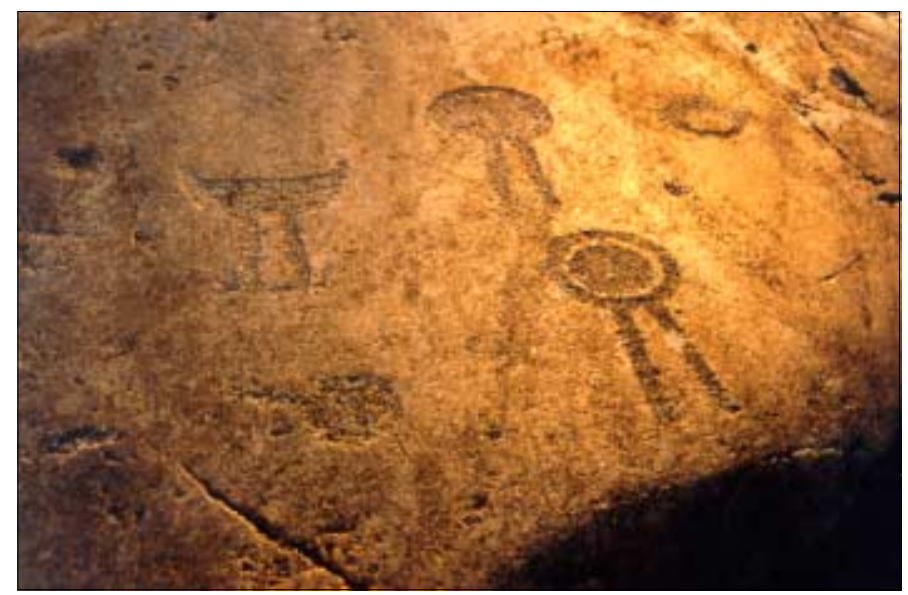

Joonis 14. Solaar- ja lunaarmärgendeid Peri VI leiukohas. Foto: V. Poikalainen. 
Kahe teadlase erimeelsus ilmneb ka selles, et kui Linevski tõlgendas enam kui 150 kujutisest koosnevat seeriat (moodustab 13\% petroglüüfide koguarvust) püüniste tõetruude kujutistena, siis nägi Ravdonikas neis kuu-ja päikesesümboleid (joonis 14). Kumbki teadlane ei näinud põhjust oma tõlgenduses kahelda. Ja kuigi vaidlus kestab tänini, paistab, et õigus oli siiski Ravdonikasel.

Iga spetsiifilise süvauuringu üldtulemus oleneb paratamatult autori lähenemismallist, kuid detailid sõltuvad siiski selgelt etnograafiast ja folkloorist leitud paralleelidest (Ernits 1990, 1994). Samal ajal kui Linevski kaldus kasutama otseseid analooge, orienteerus Ravdonikas abstraktsemate ja üldistavamate semantiliste võrdluste kasutamisele. Ravdonikase uurimissuunda jätkas $\mathrm{K}$. Lauškin, toetudes Kalevala tuumikteksti analüüsile nn "kakskeelsuse" meetodiga (bilingual method) (Lauškin 1962).

Hoolimata kõnealuste suundade ilmsest vastandlikkusest ning jäikusest on neis mõndagi ühist. Mõlema lähenemise sisuks oli transformeerida folkloorist ja etnograafiast tuntud ideid muinastaide tõlgendustesse. Loodeti, et sellise transformatsiooni abil on võimalik saavutada tõlgenduste adekvaatsus. Nii mõnedki paralleelid näivad siiski ebausutavad ning võivad olla teadlaste kujutlusvõime vili. Pealegi on niisugune lähenemine paratamatult staatiline, ning isegi siis, kui paralleelid oleksid tõesed, pole ikkagi võimalik uurida tervikut, mis moodustub erinevate petroglüüfide omavahelistes seostes. Bessi neeme Triaad on harvaesinevaks erandiks, kuna selles nähti terviklikku kompositsiooni, mida sai seostada muinaspõhjala eepiliste lugudega.

Ülaltoodut võiks illustreerida üldlevinud spekulatsioonidega uskumustest, mis seostuvad kaljutaidega. Nende hulka arvatakse maagia, totemism, päikese- ja kosmosekultus ning viljakuskultus ja nende kõikide objektiks oletatakse loomi, mitte inimesi. Animismi ei mainita, justkui oleks see tabuteema. Ka selles osas on ainsaks erandiks Ravdonikase viimases avaldatud töös pillatud märge animistliku uskumuse kohta, mis puudutas vaid ajavahemikku enne kaljutaide lõppfaasi (Ravdonikas 1956). Alljärgnevalt kavatsen näidata, kuidas kaljutaie põhineski tegelikult animistlikul teoorial ja et see kehtib kõigi kolme arengufaasi puhul.

Katsed kaljutaide semantiliseks tõlgendamiseks on siiski võrdlemisi kobavad. Tegelikult pole senini veel selge, mil viisil kajastub neoliitikumiaegse inimese maailmavaade petroglüüfides, veel vähem aga saab piiritleda konkreetsemaid uskumusi. Edasist uuri- 
mist võivad aga stimuleerida minu lähenemisviisi kaks uut aspekti. Esiteks tuleb taidekaanonite arengut käsitlevat materjali seostada piirkonna kultuuri ja etnilise ajaloo andmetega. Teiseks tuleks tõlgendada terviklikke kompositsioone, mis moodustavad koherentse entiteedi ega ole vaid üksikpetroglüüfide kogumiks.

Mis puutub esimesse aspekti, siis on oluline arvestada, et kaljutaidetraditsiooni algusperiood seostub Äänisjärve mesoliitilise kultuuri ideoloogiaga. Eriti kehtib see Bessi puhul, mida saab kaudselt seostada mesoliitikumiaegsete kõrge ühiskondliku positsiooniga isikute haudadega (vt eespool) ning tõestab ka esivanemate kultuse olemasolu.

Teist aspekti võiks näitlikustada linnutemaatikaga, mis on ainukesena esindatud kõikides Äänisjärve kaljutaide leiukohtades. Linnukujutisi kokku on umbes 500 ning need moodustavad $42 \%$ petroglüüfide koguarvust. Kolme Vodla suudmeala neeme järgi otsustades on linnumotiiv muutunud kaljutaide viimase arengufaasi kestel domineerivamaks. Märkimisväärne on see, et siiani pole seda motiivi õnnestunud usutavalt tõlgendada. Linevski ja tema koolkond (teiste hulgas ka N. Gurina) olid realistliku lähenemise pooldajatena kindlalt veendunud, et need kujutised seostuvad lindude suure osaga jahisaagis (Linevski 1939; Gurina 1956).

Mida nad aga ei arvestanud, olid arvukad etnograafilised ja folkloorsed paralleelid, mis viitasid linnu sümboolsele tähtsusele maailma seletavais animistlikes müütides. Samad paralleelid jäid märkamata ka neil, kes üritasid tõlgendada Suur-Guri (vene k Bolšoi Guri) saarel asuvat tuntud ringikujulist rühma, millel on palju ühist Kalevalast tuttava linnumunast kooruva maailma motiiviga. Isegi Bessi lääneneeme petroglüüfide hulka kuuluvat linnupeaga antropomorfset kujutist on ignoreeritud (joonised 15 ja 16).

Eriti paradoksaalsel moel leidub linnumotiivi semantilise tõlgendamise võti enamasti tähelepanuta jäänud Bessi neeme kõige silmatorkavamas kompositsioonis. Selle Triaadi Saarmast vasakul asetseva piktogrammi põhiosa koosneb suurte luigekujutiste reast. Neist profiilsetest joonistest moodustav horisontaalne pannoo, mis viitab terviklikule jutustusele, on suurim ja arvatavasti ka kõige informatiivsem terves galeriis. See sisaldab veel inimkujutist, inimest tähistavat märgendit, paati ja puud (joonis 15). Ilmselt kirjeldab see ülimalt dünaamiline ja sümboolne jooniste rühm surmajärgselt vabaneva inimhinge (näidatud väikese püstise kriipsuke- 
Joonis 15. Animalistlik kompositsioon Bessi lääneneemikult (Ravdonikas 1936).
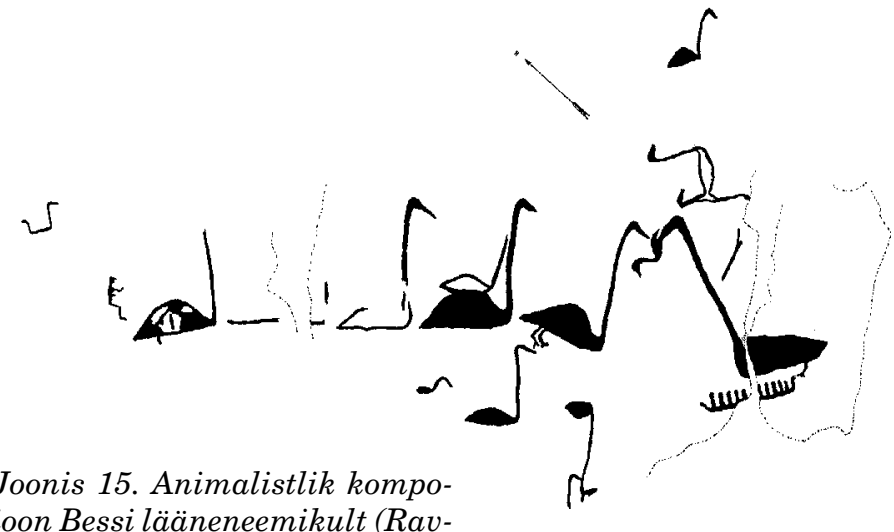

Joonis 16. Tü̈̈pilisi inim-, linnuja paadimotiive Ä̈̈nisjärve kaljujoonistes. Koopia: V. Poikalainen.
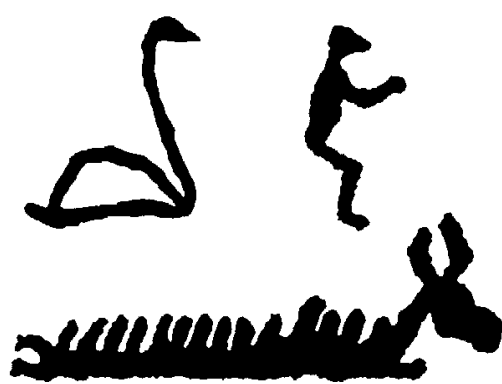

sena kõige vasakpoolsema luige kehas) kulgu. Läbinud kogu lindude rea langeb see (samuti püstkriipsukesena) parempoolse luige all paiknevasse "surnute paati" (Stoljar 1994d).

Eeldades, et petroglüüfide loomine põhineb loogiliselt ja semantiliselt animistlikel uskumustel, on kerge mõista ka hilisemat kaljutaiet Vodla jõe suudmes, kus linnukujutisi esineb eriti ohtralt ning kus asub ka hiiglaslik luigekujutis koos teiste suuremate lindudega. Uude pühamusse talletati neoliitikumiaegse usundi põhisümbolid ja nn hingede andmebaas.

Oli animism siis tõepoolest esimene ideoloogia, mis tekitas inimestes vajaduse Äänisjärve pühamu järele, või kerkis see alles hiljem esile? Mõningat tõendusmaterjali selliste või pisut algelisemate ideede kohta võib leida mesoliitikumiaegse Oleni saare matmispaiga 25 kalmust leitud linnuluude kujul, mis pärinevad 
just nendest kehaosadest, mida peeti lindude "looduslikeks sümboliteks".

Tšornaja Retška panteoni peakangelasel Kuradil näib samuti olevat hing, sest ka tema pea läheduses on kujutatud linde. Ning lõpuks asub selle kogumi suurim ja arvatavasti ka vanim luik otse oma semantilise vastandi, Saarma kõrval.

Jääb üle ainult loota, et edasine uurimistöö viib vähemalt mõne, kuigi kindlasti mitte kõigi peamiste kaljutaide põhialuste mõistmiseni.

\section{Valge mere kaljujoonised}

Võgi alamjooksu saartel Valge mere ranniku läheduses asuvad neoliitilised petroglüüfid avastati oluliselt hiljem kui Äänisjärve kaljujoonised. Nende uurimine on aga edenenud küllaltki omapäraselt.

\section{Uurimislugu}

Valge mere kaljutaide avastajaks peetakse A. Linevskit, kes 1926. aastal sattus Võgi jõel asuva Šoirukšini saare põhjaosas koseäärsele kaljule raiutud joonisrühmale (Linevski nimetas selle "galerii", algse nimega Tšortovõ Sledki (Kuradi jäljed) ümber Bessovõ Sledkiks, mis tähendab tegelikult sedasama, kuid kõlab veidi leebemalt). Hiljem avastas ta sellesarnaseid kaljujooniseid veel Jerpin Pudase saarelt, mis asub $400 \mathrm{~m}$ allavoolu (Linevski 1939).

Üsna varsti pärast Linevski lühiartiklite ilmumist saabus 1936. aastal leiukohta välitöödele sedalaadi avastusi alati pingsalt jälginud V. Ravdonikase juhitud töörühm. Seire tulemused ületasid ka kõige suuremad ootused. Lisaks Linevski avastatud petroglüüfide dokumenteerimisele leidis Ravdonikas neist rühmadest lõuna suunas uue, 68 joonisega rühma ning mitmeid seni avastamata kujutisi Jerpin Pudase saarel. Kõige sensatsioonilisemaks avastuseks osutus aga 1,5 km Šoirukšinist allavoolu asuva Bolšoi Malinini saare hiiglaslik petroglüüfipanoraam, mida peetakse tänaseni üheks suurejoonelisimaks neoliitiliste küttide tähtteoseks (Ravdonikas 1938).

Joonis 17. Valge mere kaljujooniste leiukohad Võgi jõe alamjooksul (Poikalainen 1999). 


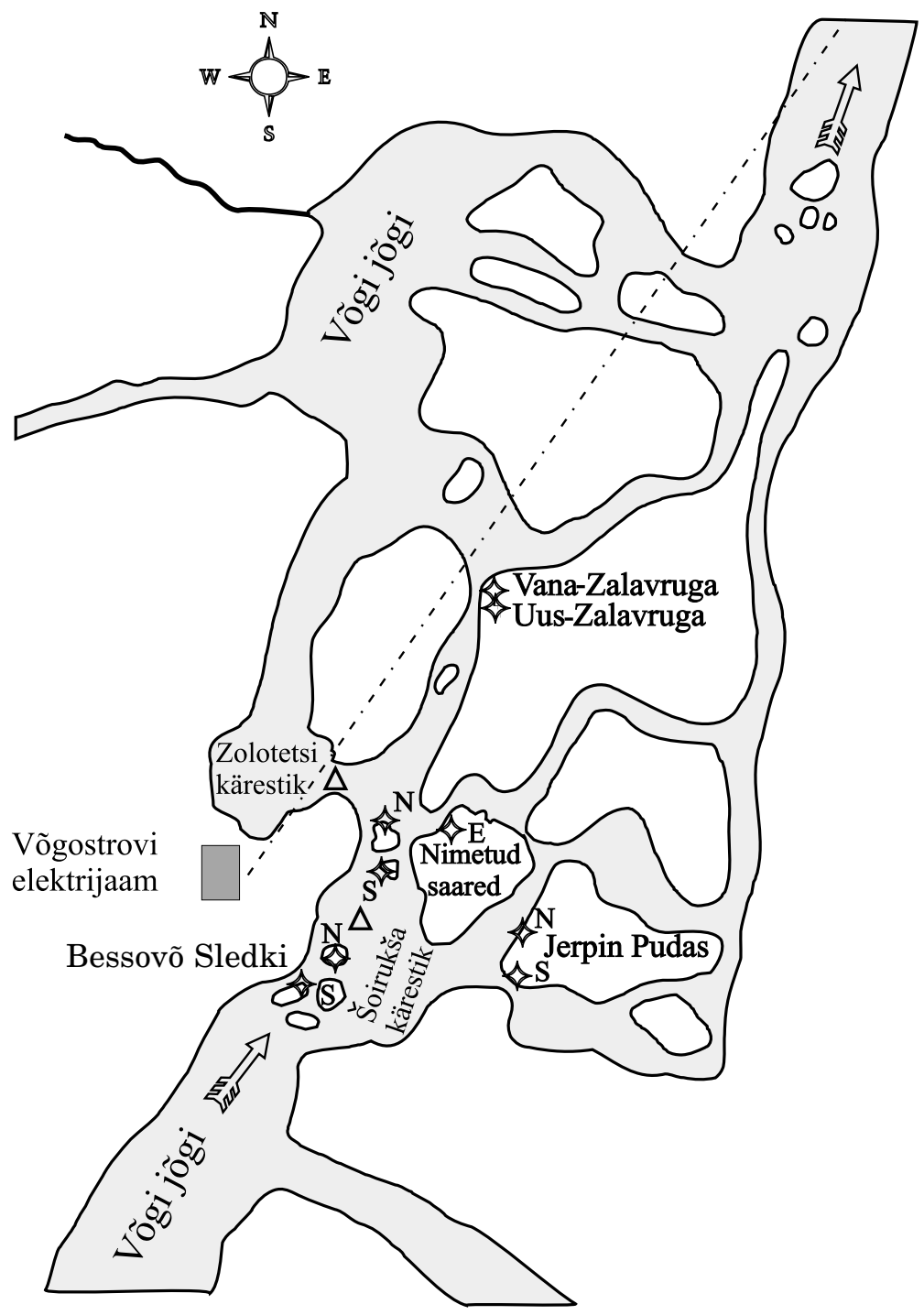

Endine jõesäng

$\Downarrow \quad$ Jooniste leiukohad $(\mathrm{N}=$ põhja-, $\mathrm{S}=$ lõuna-, $\mathrm{E}=$ ida- $)$

$\triangle \quad$ Kärestikud

- - - - - Kõrgepingeliin 
Kolmandaks, äärmiselt ootamatuks ning oluliseks sündmuseks oli Savvatejevi 1963. aastal tehtud avastus: Ravdonikase Zalavruga leiukoha lähedal leiti neoliitilise kultuurkihi alt kaljusse raiutud kujutised. Petroglüüfid puhastati viieaastaste välitööde käigus (1963-1968). Kokku leiti 1 hektari suurusel maa-alal 26 eraldiasetsevat joonisrühma (Savvatejev 1970).

Petroglüüfide koguarv kõigi rühmade peale kokku, kaasa arvatud Bessovõ Sledki ning Jerpin Pudase põhja-, kesk- ja lõunaosa (100), Vana- ja Uus-Zalavruga (vene keeles Staraja Zalavruga, Novaja Zalavruga) ning kolme väikese nimeta saare rühmad (37), on umbkaudu 2100. Eristatakse vähemalt 100 erineva keerukusastmega kompositsiooni (joonis 17).

Savvatejevi sõnul on kõige sagedamini kujutatud paati. Siiani on dokumenteeritud 265 paadikujutist, nende "meeskondadesse" kuulub kokku umbes 1000 liiget. Sellele lisandub 294 inimese, 230 metslooma (kitse, põdra, karu jm) ja 152 veeimetaja (enamasti valgevaalad ja üksikud hülged) kujutist (Savvateyev 1994). Linnukujutistel, mida on 152, paistab siin olevat pisut selgem semantiline tähendus kui Äänisjärve "animistlikel" lindudel. Lihtsad abstraktsed sümbolid (üksikud laigud, jooned jms), mille tähendus on ebaselge, moodustavad $20 \%$ petroglüüfide koguarvust. Ka need erinevad kardinaalselt Tšornaja Retška kuu- ja päikesesümbolitest.

Petroglüüfid asuvad kergelt kaldus (osalt peaaegu horisontaalsel) kaljudel, mis ulatuvad 14-22 m üle praeguse merepinna. Jooniste taustana eelistati läikivat "kõrbevaabaga" kaetud pinda.

Enamik figuure on $20-50 \mathrm{~cm}$ suurused, terve leiuala piires on kasutatud ühesugust raiumistehnikat, jooniste sügavus on 1-3 mm. Kogu sakraalne arhipelaag laiub jõe 1,5-2 kilomeetri pikkusel lõigul. On tähelepanuväärne, et see paikneb täpselt seal, kust vaalaja hülgekütid lahkusid oma ohtlikele reisidele ebasõbralikule Valgele merele. Vaalaküttimine oli riskantne ettevõtmine, kuid ainult tänu sellele suutsid rannikualade inimesed ellu jääda. Piirkonna 60 eelajaloolist leiukohta tõendavad, et neoliitilise metsavööndi kohta oli asustustihedus küllaltki arvestatav, mis tugevdas hõimudevahelist suhtlust ja rituaalset tegevust, muu hulgas ka kaljutaide viljelemist (Savvatejev 1977).

Allärgnevas keskendume Valge mere kaljutaide peamiste Bessovõ Sledki, Vana-Zalavruga ja Uus-Zalavruga - leiukohtadele. 


\section{Bessovõ Sledki}

Bessovõ Sledki peamine (põhjapoolne) rühm koosneb 40 ruutmeetri suurusest tiheda pideva vaibataolise mustri moodustavast jooniste mosaiigist (mille laius on $4 \mathrm{~m}$, pikkus $11 \mathrm{~m}$ ). Senini registreeritud petroglüüfide koguarv on 470 (joonis 18).

Joonisrühma algse tuumiku eristas ülalmainitud "topograafilist meetodit” kasutades Linevski. Esmaste jooniste hulka kuulusid suured hoolikalt raiutud teravate piirjoontega valgevaalade kontuurid. Samasuunaliselt orienteeritud vaalad paiknesid neljas eraldi rühmas, mida üksteisest eraldasid joonisteta kaljupinnad.

Iga sellist 2-3 siluetsest petroglüüfist koosnevat rühma võib käsitleda sarnaste kujutiste elementaarkogumina, millest moodustus iseseisev rituaalne üksus.

Suurte valgevaalade siluetid on raiutud $5 \mathrm{~m}$ pikkusele veepiiriga paralleelsele kaljuribale, mis viitab sellele, et sarnaselt Äänisjärve piirkonnale moodustab ka siin veepind horisondi ehk tugijoone, millega risti paiknesid vanimad kujutised. Seda tugijoont rõhutavad omakorda seitse hiljem lisatud "jalajälge", mis punktiirina juhivad antropomorfse Kuradi kujutise juurde.

"Horisondi" suhtes vertikaalsed valgevaalakujutiste varased grupid jaotusid ahelana piki veepiiri. Niisuguse standardse elemendi mitmekordsel lisamisel tekkis äärmiselt lihtne ribataoline kompositsioon. Seda võiks defineerida diskreet-homogeenseks ahelrühm-kompositsiooniks.

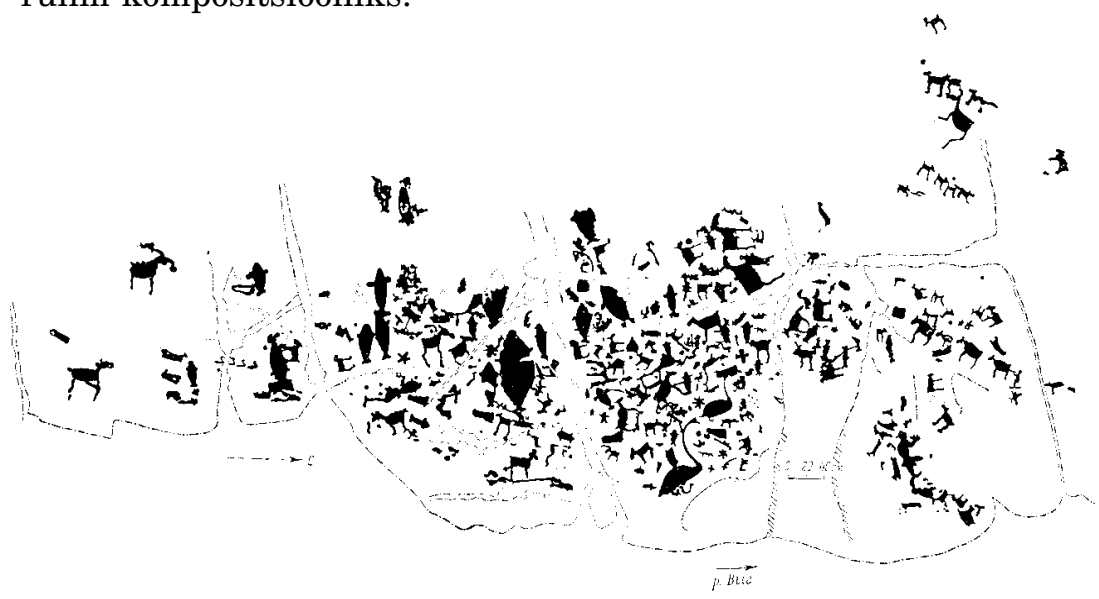

Joonis 18. Bessovõ Sledki joonised (Ravdonikas 1938). 
Topograafilised kriteeriumid võimaldavad eristada Bessovõ Sledki muistele tuumikalale tehtud varasemaid lisandeid, mis aitasid suurendada pühamu "semantilist mahtuvust". Nende hulka kuulub valgevaalade reast kirde suunas paiknev haruldane suurte luikede paar ning kalju põhjaosas asuv enam-vähem samade mõõtmetega kurat, mis esindab kolmandat (antropomorfset) lokaalkeskust joonispannoo selle osa struktuuris (Stoljar 1977).

Galerii arengu lõppfaasiks võiks pidada pikemat perioodi, mille kestel kaeti kaljupind arvukate väikesemõõtmeliste siluetsete joonistega (mis kujutasid metsloomi, paate, jalajälgi ja erinevaid sümboleid). Pannoo põhjapoolseimal serval on profiilsete petroglüüfide rida, millel on kujutatud nelja põtra jahtiv suusataja. Kunstilisest küljest on see kogum juba üsna keerukas ning võiks olla samaaegne Vana-Zalavruga kõige hilisemate kujutistega.

\section{Vana-Zalavruga}

See hiiglaslik "petroglüüfisaal”, mis asub veidi kumeral kaljul, erineb teistest mitmekülgsete kompositsioonide poolest, millest üks on eriti haruldane ja kuulus oma suurejoonelise teostuse tõttu. Selle kalju joonised ei kinnita mitte ainult sajanditepikkust taide arengut, vaid eeskätt selle taga peituva mütoloogilise mõtlemise ulatust.

Kõigepealt tuleks aga märkida, et Vana-Zalavruga leiukoht jaguneb nii motiivide, kujutiste mõõtmete kui ka loomistehnika poolest kaheks kardinaalselt erinevaks osaks: tsentraalseks pannooks, mis võtab enda alla umbkaudu $60 \mathrm{~m}^{2}$ suuruse ala (64 kujutist), ning perifeerseks kogumiks, kuhu kuulub 126 kujutist, sh 55 antropomorfset joonist (joonis 19). Topograafilised tunnused viitavad sellele, et perifeerne osa on hilisemat päritolu. Siia ulatuslikule "suurest veest" eraldatud kirdenõlvale on loodud arvukalt väiksemaid joonisrühmi ja üksikfiguure pärast seda, kui peamine graniitkuppel oli juba kaetud monumentaalsete kujutiste ridadega.

Vana-Zalavruga tsentraalne pannoo (Zalavruga Ia) on tõenäoliselt mitme põlvkonna loomingulise tegevuse tulemus. Selle moodustavad mitmed suurte profiilsete reastatud jooniste kompositsioonid, millest igaüks koosneb lähestikku paiknevatest ja rütmiliselt korduvatest hoolikalt töödeldud figuuride reast. Seda võiks defineerida nidus-homogeenseks profiilsete jooniste ahelkompositsiooniks. 


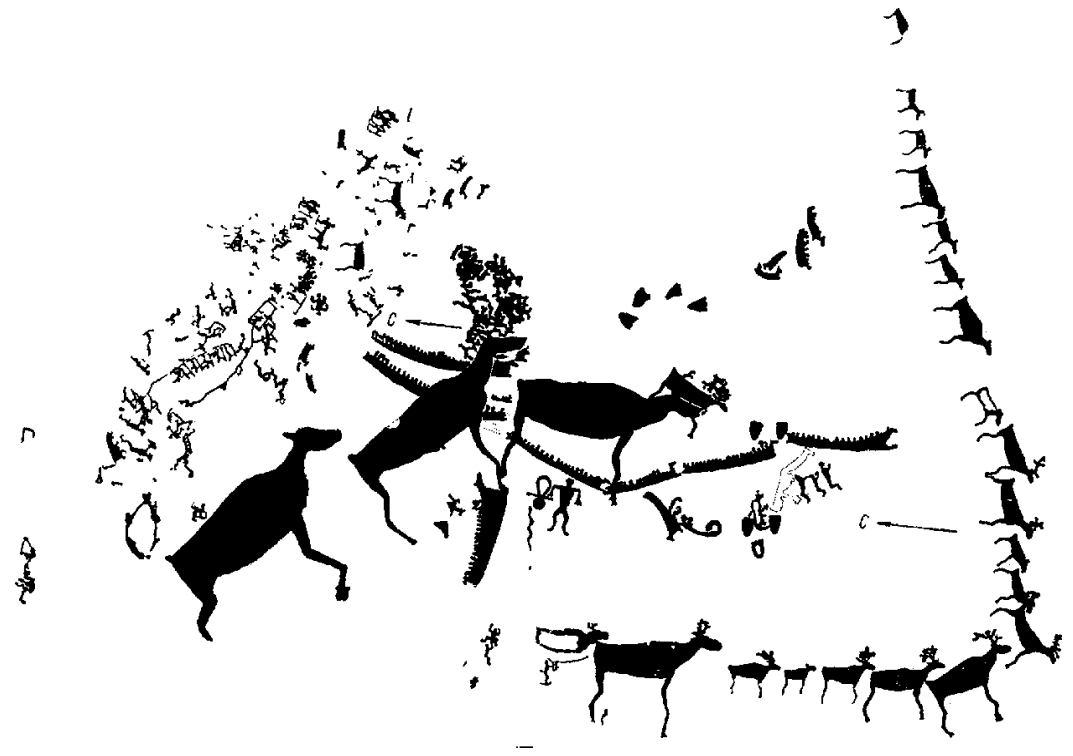

Joonis 19. Vana Zalavruga joonised (Ravdonikas 1938).

Kuna ulukpõhjapõtru ja paate on eranditult kujutatud profiilis, on nende liikumise suund kergesti tajutav, hoolimata sellest, et kõik figuurid on staatilised. Pealegi on jooniste orientatsioon samasuunaline mitte ainult ühes ahelas, vaid ka kõikides kokku.

Vana-Zalavrugast on avastatud neli seda tüüpi jooniste ahelat. Kaks neist asuvad kalju lõunaosas ning kujutavad ulukpõhjapõtrade ridu. Need moodustavad täisnurga ning kulgevad piki graniitkalju veepoolset lääne- ja lõunaserva. Kompositsiooni keskmes on kujutatud veel kahte joonisahelat, millest üks koosneb paljude inimestega mehitatud suurtest paatidest ning teine sellega osaliselt kattuvast kolmest hiiglaslikust ulukpõhjapõdrast.

Nende jooniste suhtelise kronoloogiline hindamine on võrdlemisi keerukas. Vaid üksikuil juhtudel saab seda teha kujutiste osalise kattumise analüüsiga, näiteks kahe hiiglasliku ulukpõhjapõdra peale raiutud tagumiste paatide puhul (Ravdonikase tähelepanekud). Kõikide teiste ahelate suhteliste vanuste hinnangud on enamasti hüpoteetilised. Lisaks topograafilisele materjalile saab selleks mõningal määral kasutada jooniste stiililist eripära, nt suurematena kujutati loomi hilisemal perioodil. 
Kõige tõenäolisem kronoloogia tundub olevat järgmine: (a) enamik läänepoolse rea ulukpõhjapõtrade kujutisi ning lõunapoolse rea põhiosa, mis liideti omavaheliseks nurgataoliseks tervikuks pärast läänerea valmimist; (b) paatide ahel, millistest esimesena tehti flotilli juhtiv parempoolseim paat; (c) kuues, teistest tunduvalt suurem ulukpõhjapõdra kujutis läänepoolses reas ning seda jälitav väike suusataja (kes on loomast kuus korda väiksem); (d) paremalt esimene $2,5 \mathrm{~m}$ pikkune ulukpõhjapõder, mis on kompositsiooni keskseks kujutiseks, ning kaks veelgi suuremat (kumbki 2,8 m) ulukpõhjapõdra kujutist; ja viimaks (e) terve seeria hiliseid lisandusi, mis eristuvad selgelt põhikogumist ja koosnevad peamiselt väikestest antropomorfsetest jm kujutistest, mis mõnikord ilmselgelt kuuluvad kompositsioonide koosseisu.

Kokkuvõttes illustreerib Zalavruga Ia hästi kujutiste paiknemise kumulatiivse printsiibi arengut lihtsast reastamisest keerukate kompositsioonideni, kulmineerudes motiivide integreerumisega, mille käigus erinevad temaatilised ahelad koondati üheks jutustavaks kontekstiks. Tänapäeva mõistes on need kunstilise ja vaimse integratsiooni saavutused tõeliselt täisväärtuslikud kompositsioonilised tervikud.

Vana-Zalavruga perifeerne osa (Zalavruga $\mathrm{Ib}$ ) erineb suuresti tsentraalsest pannoost, sest siin ei esine monumentaalseid joonisahelaid. Aga ka selle poolest, et kujutiste mõõtmed, mis mujal varieerusid, on radikaalselt väiksemaks muutunud. See kehtib eeskätt antropomorfsete petroglüüfide puhul.

Kui mitte arvestada ühte suusatajate protsessiooni, mida on kujutatud liikumises, ei esine siin enam Zalavruga Ia-le iseloomulikke homogeenseid ahelaid. Enamik joonisrühmadest koosneb mõnest (kohati vaid kahest) algelisest profiilsest kujutisest, mis moodustavad elementaarse kompositsiooni.

Zalavruga Ib-l domineerivad inimesekujutised, mida kohtab eriti sagedasti militaarsetes stseenides. Need on varasematest joonistest oluliselt dünaamilisemad (joonis 20). Suurem osa loomafiguure on aga endiselt staatilised. Ulukpõhjapõtra jälitav inimene on "kasvanud" loomaga ühesuuruseks ning seega ei "diskrimineerita" inimkujutist enam sel määral nagu Zalavruga Ia joonistes (joonis 21).

Zalavruga Ib-le iseloomulikud väikesed petroglüüfid erinevad aga küllatki oluliselt Bessovõ Sledki mosaiiksest pannoost. Iga stseen on teatud määral iseseisev ning vaadeldav eraldi kogumina. Kujutiste rohkus viitab mingisugusele rudimentsele tavale. Üldisest ideoloogilise olustiku muutumisest hoolimata oli osaliselt 


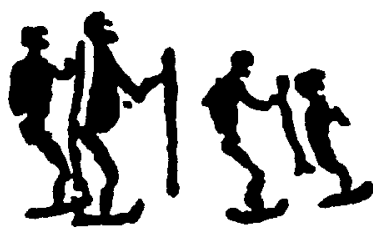

Joonis 20. Osa Vana-Zalavruga perifeersetest joonistest (Ravdonikas 1938).

säilinud ka pühamu varasem rituaalne tähendus. Ilmselt seetõttu raiutigi Zalavrugas arvukalt uusi petroglüüfe sama püha kalju perifeersele osale.

Üldiselt võttes tõendab Zalavruga Ib, mis oma päritolult on tihedalt seotud Zalavruga Ia-ga, varasemate kaanonite transformeerumist ning on perifeerne vaid oma asukoha, mitte kunstilise sõnumi poolest, mis kinnitab inimmõtte jõudmist uuele tasandile.
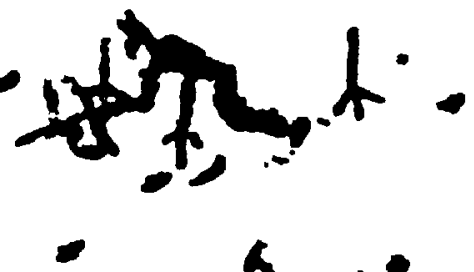


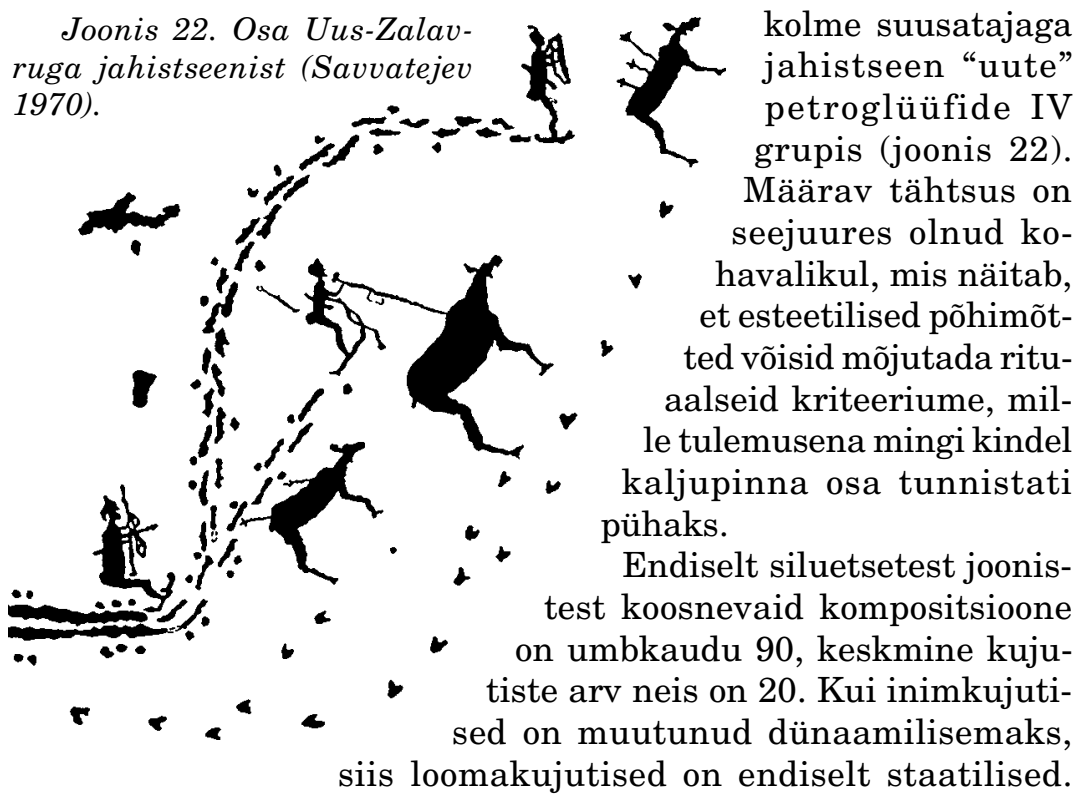

Nende profiilsete komplekskompositsioonide eripäraks võib pidada seda, et eriti just inimeste ja loomade kujutised on ühesuurused, kunstiline teostus on täiuslikum ning Zalavruga kaljutaiestes vaid vihjamisi esitatud jutustavad elemendid (suusarada, -kepid ja talvises jahipanoraamis ka relvad) arenenumad. Lisandunud on ka uusi motiive, nt kollektiivne mereloomade küttimine. Inimest esitatakse individuaalsemana kui varem - ülalmainitud kompositsiooni igal kolmest suusatajast on isikupäraseid tunnusjooni. Kõik see tunnistab uuest radikaalsest ja isegi avangardistlikust tendentsist, mis asendas suure osa eelnenud arengufaasi jäigast skemaatilisusest.

\section{Arengufaasid ja tõlgendused}

Struktuurse ja topograafilise analüüsi käigus ilmnes seega neli järjestikust faasi: (a) Bessovõ Sledki tuumikrühm; (b) Zalavruga Ia; (c) Zalavruga Ib; (d) Zalavruga II. Kõiki nelja faasi ühendab täiesti loogiline kompositsiooni arenguliin. Lisakriteeriumina võib kasutada seda, kuidas on kujutatud ulukite küttimist. Ilmseks järelduseks on see, et kõiki faase tuleb vaadelda ühtse, suletud 
süsteemina, mis vastupidiselt Äänisjärve galeriile oli arenenud iseeneslikult ilma väliste mõjutusteta.

Siiski võib selles iseseisvas arengus eristada teatud pöördepunkte. Seega moodustavad Zalavruga Ia ja Zalavruga Ib omaette tervikud, millistest kumbki tähistab kindlat ideoloogilist ja kunstilist perioodi.

Esimesel juhul on jälgitavaks suundumuseks etnokultuuriliste sümbolitega (loomade, paatide read) liialdamine, mis peegeldab mingi ideoloogilise nihke põhjustatud kaitsereaktsiooni.

Järgmises staadiumis (Zalavruga Ib) kerkib esile terve hulk erinevaid, täiesti uusi elemente, milles domineerib tegutseva inimese kujutis. Jahi- ja ilmselt militaarsed stseenid on küllaltki dünaamilised. Selline dramaatiline muutus loomingulises olustikus ja uudne rõhuasetus sõjamotiividele viitab mingile erakordsele asjaolule, mis pidi muutma elu tavapärast kulgu. Siinkohal tasub meenutada, et Linevski, kes oli oma vaadetes küllaltki järjekindel, tõlgendas neid kompositsioone kui kroonikat ning hõimudevaheliste konfliktide peegeldust.

Vastupidiselt "isolatsionistlikule" teooriale, milles petroglüüfide arengut nähakse läbinisti iseseisva protsessina, tuleks meil veel kord pöörduda tagasi 3. at lõpus eKr aset leidnud Volossovo-Garino elanike rände juurde. Arvukate poorse keraamika ja miniatuursete ränifiguuride leidude põhjal ilmneb, et selle põhjapoolseim laine oli eriti võimas. Erinevalt Äänisjärvel toimunust olid aga siin sisserännanute ja kohalike hõimude vahelised suhted algusest peale vaenulikud (Stoljar 1994c). Selle põhjuseks võisid olla mitmed asjaolud, sh konkurents toidu pärast soodsas ökoloogilises nišis, mereloomaküttide vaenulikkus ning arvatavasti ka keelebarjäär. Petroglüüfitraditsiooni rikastamise asemel põhjustas selline vastasus pigem psühholoogilise konflikti. Ometigi soodustas ka vastuseis sisserännanute kultuurile taide arengut ning mingil moel suurendas inimkujutiste osatähtsust.

Aktsepteerides hüpoteesi, et teatud ajaloolised sündmused Valge mere rannikul ja kaljutaide areng on omavahel seotud, osutub võimalikuks ka nende rühmade dateerimine. Üldise arvamuse põhjal on Bessovõ Sledki tuumikalal asuvad petroglüüfid kõige vanemad. Bolšoi Malinini saarel asuvate teiste petroglüüfirühmade kohta arvab Savvatejev, kellelt pärineb põhiosa teadaolevast informatsioonist, et Uus-Zalavruga on vanem kui Vana-Zalavruga. Ülalpool esitatud tõendid näivad toetavat pigem vastupidist. 
Savvatejev (1970, 1977, 1983; Savvateyev 1994) ei olnud järjekindel erinevate rühmade kronoloogia käsitlemisel. 1970. aastal avaldas ta arvamust, et kronoloogilised piirid on üsna kitsad, 1977. a aga väitis, et petroglüüfe võidi luua kuni 1500 aasta jooksul. Vaatamata erinevate dateerimismeetodite olemasolule (õietolmuanalüüs, paleogeograafia, radiosüsinikumeetod ja arvukatest kohtadest avastatud arheoloogilised leiud) on see küsimus erinevate kriteeriumide vahel valitseva ebakõla tõttu senini lahtine (vt Arheologija 1996: 145-146).

Kronoloogia kohta pole just palju öelda. Väga üldistatult võib petroglüüfe dateerida 4. ja 3. aastatuhandesse eKr ja on ka põhjust arvata, et neid loodi pika aja vältel. Bessovõ Sledki "galeriid" saab dateerida isegi 4. at algusse eKr. Samuti võib veel oletada, et Valge mere petroglüüfid pärinevad varasemast ajast kui Äänisjärve omad. Tänaseni pole siiski seda oletust olnud võimalik kontrollida.

Niisuguse ebakindluse juures on aga eriti oluline analüüsida arheoloogilisi andmeid, mida pole selleks otstarbeks veel kasutatud. Nimelt võiks üritada seostada järske muutusi kaljutaide arengus arheoloogiliste leidude põhjal rekonstrueeritud sündmustega. Üheks selliseks on Volossovo-Garino rahvaste ränne Valge mere piirkonda 3. at teisel poolel eKr. Zalavruga Ia, aga eriti Zalavruga Ib näivad seostuvat selle sündmusega. Juhul kui see on nii, tuleks Uus-Zalavrugat (Zalavruga II) dateerida 3. at lõppu - 2. at algusesse eKr. Seega võib Volossovo-Garino rahvarännet kasutada tugipunktina nii Äänisjärve kui ka Valge mere petroglüüfide dateerimisel.

\section{Kaljutaide leiualade võrdlus}

Kui ülalmainitud oletus peab paika, pole enam võimalik rääkida ühtsest Karjala kaljutaidest, kuna mõlemad keskused arenesid suures osas iseseisvalt ning reageerisid samale migratsioonile täiesti erinevalt. Sarnasused osutuvad tõepoolest vaid pinnapealseks. Kuigi mõlemas paigas koondusid petroglüüfid veepiiri lähedale, oli topograafiline kontekst siiski erinev, seega pidi ka nende pertseptsioon olema erinev. Samas kui Valge mere kaljutaide leiukohad moodustasid suletud sakraalse arhipelaagi, laius Äänisjärve "galerii” $10 \mathrm{~km}$ pikkusel amfiteatritaolisel rannaribal vaatega mõõtmatule veele ja taevalaotusele, kus ringlesid tähed ja planeedid. 
Sedasama võib täheldada ka vormilt sarnaste (animalistlike) täävidega paadikujutiste kohta mõlemas keskuses. Paadikujutised ei erine pelgalt konstruktsioonilt (mis oleks iseenesest mõistetav), vaid ka semantilise tähenduse poolest. Nad kajastavad ilmselt vastandlikke ideid (Äänisjärve "surnute paadid" versus üsnagi elutruud Zalavruga II tegelikud paadid, mida kasutasid Valge mere äärsed elanikud). Sama võib öelda ka Valge mere linnukujutiste kohta. Erinevalt Äänisjärve animalistlikest linnusümbolitest tuleb neid käsitleda reaalsete lindudena. Ka "märgendid" on erinevad Äänisjärve abstraktsed astraalsed sümbolid (umbkaudu 100 tk) versus Valge mere elementaarsed punktid, laigud, kriipsukesed, millega tõenäoliselt tähistati mingeid erilisi tegevusi.

Kui Äänisjärvel on mõned "märgendid" raiutud ka loomafiguuride sisse, siis Valge mere kompleksis seda ei esine. Erinevalt Äänisjärve panteoni küpse arenguperioodi abstraktsetest ja fantastilistest ideogrammidest (nt need, mis asuvad Karetski neemel) on UusZalavruga joonisterühmad küllaltki realistlikud. Mereloomade küttimise motiivid ja suusatajate kujutised on iseloomulikud Valge mere piirkonnale, kuid puuduvad Äänisjärvel. Ka inimkujutiste esinemise sagedus on kummaski keskuses oluliselt erinev.

Mis puutub stiililistesse erinevustesse, siis on enamik Valge mere figuure kujutatud väga dünaamiliste ja profiilsetena. Vastupidiselt Äänisjärvele, kus inimfiguurid paiknevad enamalt jaolt eraldi (v.a üksikud juhud, kus kujutatakse sugulist vahekorda), esinevad inimesed siin rühmadena. Kui enamik Äänisjärve inimkujutistest on enam-vähem ühesuurused (v.a vanim joonis Bessi neeme Triaadis), siis Valge mere regioonis on nähtav inimkujutiste evolutsiooniline suurenemine. Zalavruga Ia "mikroskoopilised" suusatajad asenduvad aja jooksul aina suuremate kujutistega, kuni jõuavad hilisemates rühmades jahitavate loomafiguuridega suuruse poolest samale tasemele (vt joonis 21 ).

Relvi, riietust ja peakatteid kujutatakse detailselt ning Zalavruga II inimkujutistele on omistatud ka individuaalseid jooni. Kuna Valge mere kaljujoonistes hakati üha rohkem tähelepanu pöörama inimesele (eriti mereloomade jahistseenides), ei käsitletud inimesi enam pelgalt paadimeeskonnana. Kui varasemad inimfiguurid on kujutatud paadist vaid vaevu välja ulatuvate kriipsukestena, nagu Zalavruga Ia "flotillis", siis hilisemates (Uus-Zalavruga) paatides esinevad täispikkuses figuurid, mis pääsevad eriti mõjule IV rühma valgevaala küttimise stseenis, kus võidi kujutada isegi konkreetseid isikuid (joonis 23 ). 


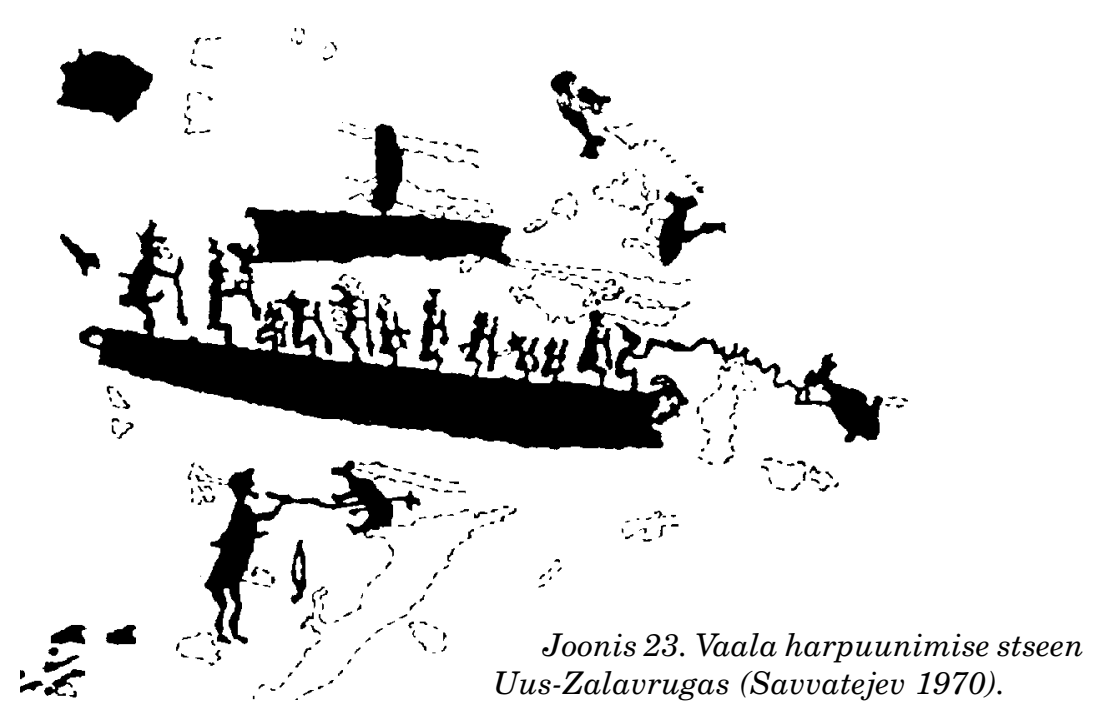

Need erinevused on eriti olulised juba seetõttu, et kajastavad kummagi pühamu erinevaid ideoloogilisi suundumusi, millised võisid tuleneda erinevast looduslikust kontekstist. Valge mere joonised keskenduvad jahimaagiale (nii merel kui ka metsas), kuid neis on vähem pööratud tähelepanu animalistlikele ja astraalsetele motiividele. Mõned joonisrühmad näivad kujutavat initsiatsiooniriitusi. See kehtib eriti ülalmainitud IV rühma valgevaala küttimise stseeni puhul, mis üsna tõetruult kujutab riituses osalejaid ja ilmselt neid juhendavat õpetajat (vt joonis 23).

Mõlema territooriumi petroglüüfide võrdluse põhjal saab järeldada, et nad erinevad teineteisest väga olulisel määral nii abstraktsuse, üldistatuse, emotsionaalsuse kui ka loogilisuse ning lõpuks kogu ideoloogilise tausta poolest. On märkimisväärne, et sõjaeelsest arheoloogilisest arenguteooriast lähtudes liigitas Ravdonikas (1937a, 1937b) need keskused primitiivse mõtlemise arengu erinevatesse faasidesse - maagilisse (Valge meri) ja kosmilisse (Äänisjärv).

Mis võis siis olla peamine tegur, mis põhjustas nii tohutu erinevuse nende kahe Põhja-Euroopa neoliitilise taideilmingu vahel, mille loojateks oli kaks end ühtviisi korilusega elatavat populatsiooni? Valge mere keskus paikneb taigavööndis. Karm kliima oli aga paradoksaalsel kombel selle haruldase ökoloogilise niši hõlvanud inimestele siiski küllaltki soodne. Eduka mereloomade (ja arva- 
tavasti ka ulukpõhjapõtrade) küttimise tõttu pidi asustustihedus olema võrdlemisi suur, muutes nii ka kogukonna elu aktiivsemaks. Küttimine osutus võimsaks kollektiivse emotsionaalsuse generaatoriks, mille tulemuseks on petroglüüfidel kujutatud reaalsed ja rituaalsed jahistseenid. Valge mere jooniste temaatika on piiratum kui Äänisjärve oma, mis võis olla tingitud jahiriituste hooajalistest erinevustest (nimelt võidi kevadpidustusi viia läbi Äänisjärve ääres, aga mitte Valge mere rannikul).

Toimida võisid ka muud tegurid. Kardinaalselt erinev viis, kuidas need kaks inimrühma reageerisid ühele ja samale ajaloolisele sündmusele (Volossovo-Garino elanike sisserändele), viitab asjaolule, et Valge mere ja Äänisjärve asukad võisid kuuluda erinevatesse etnilistesse rühmadesse ning võimalik, et olid vastavalt protosaamid ja protosoomlased.

Hoolimata kõigist erinevustest oli mõlema pühamu sotsiokultuuriline tähtsus siiski üldjoontes sama. Esmakordselt kerkis esiplaanile arusaam inimesest kui sotsiaalsest jõust. Seda ideed kehastav hõimu protokangelane võis olla Väinämöise eelkäija. Mitte vähem tähtis pole see, et pühamute lähedal peetud hooajalised pidustused edendasid hõimudevahelist suhtlemist ning toimisid seega etnogeneetiliste protsesside katalüsaatorina.

\section{Kokkuvõte}

Põhja-Venemaa Euroopa osa (Peterburist põhja pool asuvate alade) inimasutuse varaseimat perioodi juba pikemat aega uurinud teadlased on seisnud silmitsi mitmete probleemidega.

18. sajandi alguses peeti Laadoga piirkonnast leitud üksikuid jutuleide lihtsalt rariteetideks. 19. sajandil kogusid N. Butenev, E. Eichwald ja eriti I. Poljakov juba rohkeid leide Olonetsi kubermangust. Avastati vaid üksikuid asulakohti; enamik neist jäid tihedates metsades ja soodes leidmata. Lisaks sellele takistasid teadlaste otsinguid ka ekslikud teooriad inimasustuse vanusest neis paigus.

Vorso teos Põhjala muistised, mis käsitleb Skandinaavia arheoloogiat ja on tõlgitud ka vene keelde, ning von Baeri mõjukad argumendid selle kohta, et oletatavasti tungis inimene sellesse piirkonda alles hilisemal ajajärgul (tema arvamust mööda pidi see toimuma Siberi suunast), jahutasid teadlaste lootusi avastada piirkonnast muistsete kultuuride jäänuseid. 
Esimese tõsisema katse tuua päevavalgele Venemaa põhjaosa eelajaloolise inimasustuse jälgi tegi A. Inostrantsev, kes aastatel 1878-1882 töötas Laadoga lõunarannikul ning üritas oma väljakaevamistel rakendada geoloogilist meetodit. 19. sajandi lõpus jäid isegi need fundamentaalsed uuringuid vaid mööduvaks nähtuseks, kuna 1880ndatel aastatel nihkus uurijate tähelepanu Lõuna-Venemaa kääbaskalmete ehk kurgaankultuuridele.

1922. aastal jätkati Karjalas arheoloogilisi uuringuid ning avastati uusi holotseeniaegseid asulakohti. Teoreetilisel tasandil oli edasiminek siiski peaaegu olematu. Valitseva arvamuse kohaselt olid Karjala ja sellega külgnevate tsirkumpolaarsete alade hilise kiviaja kultuurid mahajäänud, arhailised ja konservatiivsed ega olnud võimelised ideoloogilisteks uuendusteks. Põhja ja lõuna vahelist lõhet teravdas veelgi neoliitilise revolutsiooni kontseptsioon, mis keskendus peamiselt majanduse arengule.

Veidi enne Teist maailmasõda tehtud neli tähtsat avastust muutsid oluliselt neid arusaamu. Need avastused olid:

1) Barentsi mere ranniku "arktiline paleoliitikum" ehk Komsa kultuur,

2) hiiglaslik Oleni saare kalmistu,

3) monumentaalsed "petroglüüfigaleriid" Äänisjärve idaosas ja

4) Valge mere rannikul (Võgi jõe suudmes).

Tegelikult hakkab nende leiukohtade õige tähendus selguma alles nüüd.

“Arktilise paleoliitikumi” tähtsus seisneb selles, et tänapäeva arusaama kohaselt asustati Fennoskandia põhjaosa ja Koola poolsaar üheaegselt. Veidi vähem levinud on arvamus, et Oleni saare kalmistu, mille (Filatova algatatud) kronoloogilisele aktsepteerimisele kulus umbes 50 aastat, on mesoliitikumi arenenud perioodi tundmaõppimisel ja selle ideoloogiliste tunnuste hindamisel määrava tähtsusega.

Karjala kuulsad petroglüüfide leiualad tähistavad neoliitilise inimarengu kõrgpunkti ning on sellistena tähtsad mitte ainult Põhja-Euraasia korilusühiskondades, vaid kogu üldises kultuuriajaloos. Nende kandvaks ideeks on inimtemaatika esiletõus ja selle tulemusel tekkinud hõimukangelase arhetüüpne kujutelm. Sellel taustal eristuvad mitmed spetsiifilised tunnusjooned, mis tõendavad nii Äänisjärve kui ka Valge mere elanikkonna etnilist ja arvatavasti ka keelelist mitmekesisust.

Ülalesitatud neli muististe kogumit moodustavad kronoloogilise rea mesoliitikumist hilisneoliitikumini. Kuigi neil on mitmeid ühi- 
seid tunnuseid, ei moodusta nad ometigi korrapärast arengurida. On tõenäolisem, et neid muististe kogumeid eraldasid üksteisest pikad ajavahemikud. Muististega on kajastatud vaid üksikud episoodid piirkonna suures osas veel avastamata sotsiaalsest ja kultuurilisest ajaloost. Samas peegeldavad nad ajuti muutusi ideoloogias, nagu näiteks üleminekut puuiidolitelt nende petroglüüfidest "varjude" kasutamisele.

Koola poolsaare "arktilisele paleoliitikumile" (u 10000 aastat tagasi), mida nüüdseks on hakatud nimetama varaseks mesoliitikumiks, oli arvatavasti iseloomulik piirkonna sajanditepikkune algne asustamine arvukate rändrühmade poolt ning inimese kohanemine äärmiselt karmi kliimaga.

Aastatuhandeid hiljem, kui etnilised, sotsiaalsed ja kultuurilised protsessid aktiviseerusid, olid vaimse traditsiooni jätkajateks inimesed, keda esindavad Oleni saare kalmistu leiud. Siin sooritasid erinevad, arvatavasti Povenetskaja Guba ümbruse asukate rühmad ühiselt matuseriitusi. Need esivanemate kultusele keskendunud toimingud moodustasid vajaliku ideoloogilise tausta etnokultuuriliste protsesside edasiseks kulgemiseks.

Neoliitikumis (umbkaudu 4000-3000 aastat eKr), suures osas tänu ideoloogilistele tõekspidamistele, tihenesid kontaktid inimpopulatsioonide vahel (D. Bubrichi sõnutsi oli see etniliste koosluste tekke üheks eelduseks). Kaljutaidekeskuste ainestik tõendab ka seda, et põliselanike ja sisserännanute sotsiaalset integratsiooni kiirendas mütoloogiate assimilatsioon.

Erinevalt Oleni saare kalmistust, mis lisaks pühamule leidis ka praktilist kasutust, oli petroglüüfigaleriidel puhtalt rituaalne otstarve. Nende põhifunktsioon oli ületada väikeste isoleeritud inimrühmade kollektiivse mõtlemise kitsavõitu piirid ja luua üldine ettekujutus universumist (piisab, kui meenutada arvukaid kuu-ja päikesesümboleid, mis on raiutud Peri neeme kaljudele). Keskne kujutis, mis domineeris terves semantilises taustsüsteemis, oli aga inimene.

Petroglüüfigaleriisid Karjalas, aga ka Norras (Vingen ja Alta) Rootsis (Nämforsen) on juba pikka aega tunnustatud muinastaide väärikate näidetena (vt ka joonis 1). Ometigi on nende ajaloolist tähtsust suuresti alahinnatud.

Et üle saada traditsioonilisest arvamusest, mille kohaselt petroglüüfe käsitletakse vaid kujutistena, tuleks tutvuda V. Vernadski ja P. Teilhard de Chardini ideedega inimfenomeni vaimsest olemusest. 
Praegune teoreetiline arheoloogia sarnaneb mõneti 19. sajandi "paleoetnograafiale", mille dogmade järgimisel on uurijad end leidnud Teilhardi väljendit kasutades poolel teel tõeni. Arheoloogia omistas tõepoolest ülemäärast tähendust materialistlikule arengule, kuid jättis kõrvale teise, palju olulisema aspektina sotsiaalse mentaalsuse. Viimastel aastatel ilmneb see suundumus veelgi teravamalt tänu mõjukale "neoliitilise revolutsiooni" teooriale, mille kohaselt edumeelne Lõuna ületab eeldatavalt tagurlikku Põhjalat igas mõttes.

Neoliitilise Fennoskandia põhjal on aga raske nõustuda sellise väärika teadusliku folklooriga. Hiiglasuured petroglüüfigaleriid meenutavad pigem eelajaloolisi katedraale, mis täitsid erinevaid funktsioone ja peegeldavad tolleaegset etnokultuurilist arengulugu, sh varemalt lahus elanud ja arvatavasti ka keeleliselt mitmekesiste inimrühmade kultuurikontakte. Ilmselt lõi soodsa pinnase etniliseks ja kultuuriliseks integratsiooniks just ideoloogia, mitte majandus (Stoljar 1994a). Emotsionaalsusest tulvil rituaalid, mida petroglüüfipühamutes erinevatel eesmärkidel (muu hulgas hõimudevaheliste abielude pühitsemiseks) regulaarselt peeti, kiirendasid integratsiooniprotsesse, mille käigus muutusid hajutatud inimpopulatsioonid üheks suureks kogukonnaks. Nende eelajalooliste rituaalide jäänukiks näivad olevat ka tänapäevased traditsioonilised pidustused, nagu Amuuri karupühad, nganassaanide valgusepäev ja saamide karasjok. Ka need pidustused täidavad sama eesmärki - säilitada etnilist ühtsust.

Integreeriv element ilmneb eriti just Äänisjärve galeriis (vt ülalpool). Võib arvata, et ideoloogiline funktsioon oli terves PõhjaEuraasia metsavööndis enam-vähem sama. Seega pidid ka selle piirkonna etniliste protsesside põhijooned paljuski kattuma.

Teine asjaolu, mis väärib märkimist, on see, et petroglüüfidel kujutatu ei ole semantiliselt lõpetatud. Võib arvata, et sakraalse sisuga loomisprotsessi käigus lisati neile hiljem detaile ja liideti külgnevate kujutistega. Neid galeriisid võib seega pidada ka eelajalooliste taidurite töökodadeks.

Kokkuvõtlikult öeldes Oleni saare võimast ideoloogilist traditsiooni järginud Karjala neoliitikumil (mil anastav majandamine saavutas kõrge arenguastme) oli märkimisväärne panus inimkultuuride arengusse ja integratsiooni. 


\section{Kirjandus}

Arheologija 1996 = Arheologija Karelii. Petrozavodsk.

Bednarik 1992. A new method to date petroglyphs. Archaeometry $34_{2}$, lk 279-291.

Ernits, E. 1990. O semantike onežskihh petroglifov. Problemõ izutšenija naskalnõhh izobraženii v SSSR. Moskva, lk 26-29.

Ernits, E. 1994. Tema kosmitšeskoi ohhotõ v onežskihh petroglifahh. Tezissõ dokladov na meždunarodnoi konferentsii, posvjaštšjonnoi 100-letiju so djna roždenija professora V. I. Ravdonikasa. Sankt-Peterburg.

Gurina, N. N. 1956. Oleneostrovski mogilnik. Materialõ $i$ issledovanija po arheologii 47. Moskva \& Leningrad.

Lauškin, K. D. 1962. Onež skoje svjatilištše II. Skandinavski sbornik. Tallinn, lk 177-298.

Linevski, A. M. 1939. Petroglifõ Karelii. Petrozavodsk.

Poikalainen, V. 1994. Karelian petroglyphs on the computer-screen. Tezissõ dokladov na meždunarodnoi konferentsii, posvjaštšjonnoi 100-letiju so djna roždenija professoraV. I. Ravdonikasa. Sankt-Peterburg, lk 29-30.

Poikalainen, V. 1995. Some statistics about the rock-art of lake Onega. Drevnosti severo-zapadnoi Rossii. Sankt-Peterburg, lk 26-29.

Poikalainen, V. 1999. The Diffusion of Swan and Whale motifs in Karelian Rock Art. Gustafsson, A. \& Karlsson, H. (toim). Glyfer och arkeologiska rum - en vänbok till Jarl Nordbladh. Lk 699-717.

Poikalainen, V. \& Ernits, E. 1990. K opisaniju i interpretatsii novootkrõtõhh finno-ugorskihh petroglifov na beregu Onežskovo ozera. Fennougristika 16. Tartu, lk 104-111.

Poikalainen, V. \& Ernits, E. 1998. Rock carvings of Lake Onega. The Vodla Region. Tartu.

Ravdonikas, V. I. 1936. Naskalnõje izobraženija Onežskovo ozera. Moskva \& Leningrad.

Ravdonikas, V. I. 1937a. Sledõ totemistitšeskihh predstavlenii v obrazahh naskalnõhh izobraženii Onežskogo ozera i Belogo morja. Sovetskaja arheologija III, lk 3-32

Ravdonikas, V. I. 1937b. Elementõ kosmitšeskihh predstavlenii v obrazahh naskalnõhh izobraženii. Sovetskaja arheologija IV, lk 11-32.

Ravdonikas, V. I. 1938. Naskalnõje izobraženija Belogo morja. Moskva \& Leningrad.

Ravdonikas, V. I. 1940. Neolititšeski mogilnik na Onežskom ozere. Sovetskaja arheologija VI, lk 46-62.

Ravdonikas, V. I. 1956. Neolititšeski mogilnik na juž nom Olenem ostrove Onež skovo ozera (vt Gurina, N. N. 1956. Oleneostrovski mogilnik. Materialõ $i$ issledovanija po arheologii 47), lk 7-24.

Savvatejev, J. A. 1970. Zalavruga I. Petroglifõ. Leningrad.

Savvatejev, J. A. 1977. Zalavruga II. Stojanki. Leningrad.

Savvatejev, J. A. 1983. Naskalnõje rissunki Karelii. Petrozavodsk. 
Savvateyev, Y. 1994. Les gravures de la mer Blanche. Lettre internationale d'informations sur l'art rupestre 7, lk 22-27.

Stoljar, A. D. 1977. Opõt analiza kompozitsionnõhh struktur petroglifov Belomorja. Sovetskaja arheologija 3, lk 12-32.

Stoljar, A. D. 1978. O genetitšeskoi prirode "Bessa" Onežskihh petroglifov. Problemõ arheologii II. Leningrad, lk 209-221.

Stoljar, A. D. 1983. "Žezlõ" onežskihh petroglifov i ihh materialnõje prototipõ. Izõskanija po mezolitu i neolitu SSSR. Leningrad, lk 145-158.

Stoljar, A. D. 1994a. Problema sotsiokulturnoi reabilitatsii lesnogo neolita Karelii. Problemõ arheologii 3, lk 29-53.

Stoljar, A. D. 1994b. Peretšitõvaja "Petroglifõ Karelii” Aleksandra Mihhailovitša Linevskogo. Vestnik Karelskogo krajevedtšeskovo muzeja 2. Petrozavodsk, lk 3-10.

Stoljar, A. D. 1994c. Petroglifõ Belomorja kak subjekt kulturno-istoritšeskovo progressa ( $\mathrm{k}$ probleme kosvennogo otraženija negativnogo kontakta). Materialõ $k$ plemenõ "Izutšenije drevnihh kultur $i$ tsivilizatsii". Sankt-Peterburg, lk 59-63.

Stoljar, A. D. 1994d. "Lodki mjortvõhh" (V. I. Ravdonikas) onežskogo petroglifitšeskogo svjatilištša. (Opõt immanentnoi dešifrovki). Tezissõ dokladov na meždunarodnoi konferentsii, posvjaštšjonnoi 100-letiju so djna roždenija professora V. I. Ravdonikasa. Sankt-Peterburg, lk 30-33.

Stoljar, A. D. 1995a. Drevneiši plast petroglifov Onežskogo ozera (k postanovke problemõ). Peterburgski arheologitšeski vestnik 9. Sankt-Peterburg, lk 85-95.

Stoljar, A. D. 1995b. Oleneostrovski mogilnik i jego pogrebenije No 100 kak agentõ mezolititšeskogo Severa. Drevnosti severo-zapadnoi Rossii. Sankt-Peterburg, lk 16-22.

Zamjatnin, S. N. 1948. Miniatjurnõje kremnevõje skulpturõ v neolite severo-vostotšnoi Jevropõ. Sovetskaja arheologija X, lk 85-123. 